\title{
AVALIAÇÃO DO EFEITO DE INOCULANTE BACTERIANO SOBRE A QUALIDADE DE SILAGEM E DESEMPENHO ANIMAL
}

JOZIVALDO PRUDÊNCIO GOMES DE MORAIS

Engenheiro Agrônomo

Orientador: Prof. Dr. CELSO BOIN

Dissertação apresentada à Escola Superior de Agricultura "Luiz de Queiroz", da Universidade de São Paulo, para obtenção do título de Mestre em Agronomia, Area de Concentração: Ciência Animal e Pastagens.

PIRACICABA

Estado de São Paulo - Brasil

Novembro - 1995 
Morais, Jozivaldo Prudêncio Gomes de

Avaliação do efeito de inoculante bacteriano sobre a qualidade de silagem e desempenho animal / Jozivaldo Prudêncio Gomes de Morais. - - Piracicaba, 1995.

77p. : il.

Dissertação (Mestrado) - - Escola Superior de Agricultura Luiz de Queiroz, 1995. Bibliografia.

1. Gado nelore - Alimentaçāo 2. Rumen - Fermentaçāo 3. Silagem de milho Digestibilidade 4. Silagem de milho - Qualidade I. Título 


\section{AVALIAÇÃO DO EFEITO DE INOCULANTE BACTERIANO SOBRE A QUALIDADE DE SILAGEM E DESEMPENHO ANIMAL}

JOZIVALDO PRUDÊNCIO GOMES DE MORAIS

Aprovada em: 11.12.1995

Comissão julgadora:

Prof. Dr. Celso Boin

ESALQ/USP

Prof. Dr. Max Lázaro Vieira Bose

ESALQ/USP

Prof. Dr. Wagner Lavezzo

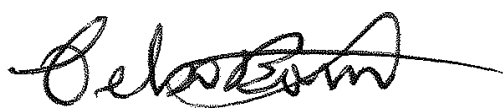

Prof. Dr. Celso Boin

Orientador 
Ao meu pai Domingos Prudêncio de Morais (in memorian), à minha mãe Maria Conceição Gomes de Morais e a todos da minha família.

À minha mulher Regina Lucia, e a Lorena e Letícia, pelos anos de convivência. 


\section{AGRADECIMENTOS}

-Ao Prof. Dr. Celso Boin pelos ensinamentos e orientação no decorrer do curso de mestrado;

- À Regina Lucia, pelo apoio durante a execução do curso e pelo valioso trabalho de revisão;

- Ao Prof. Dr. Max L. V. Bose, pela amizade e apoio durante o curso de mestrado;

- $A$ Coordenadoria de Aperfeiçoamento de Ensino Superior (CAPES), pela concessão da bolsa de estudo;

- $\grave{A}$ Pioneer Sementes Ltda pelo financiamento da primeira fase desta dissertação;

-Ao Prof. Dr. Wilson Mattos pela concessão do Laboratório de Bromalogia;

- Ao laboratorista Cesar Alves, pela amizade e apoio nas realização das análises;

- Ao José Carlos, pelos ensinamentos de práticas de laboratório;

- Ao Luiz Gustavo Nussio, pelas sugestões e apoio na primeira fase do trabalho;

-Ao grande amigo João Ricardo pelo auxílio na condução da primeira parte dos ensaios;

-Ao amigo Fábio Campos pelo auxílio na condução da segunda fase dos ensaios;

- Aos amigos Celso Faria e Marcia Machado pelo grande auxílio em toda segunda fase dos ensaios;

- À Roberta Carvenalli, pelo grande colaboração nas análises laboratoriais;

- Ao Clube de Práticas Zootécnicas (CPZ), pela disposição e auxílio na condução do trabalho;

-Ao amigo Maurício Salviano pelo apoio prestado no transcorrer do curso. 


\section{SUMÁRIO}

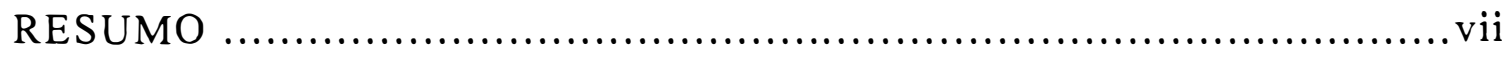

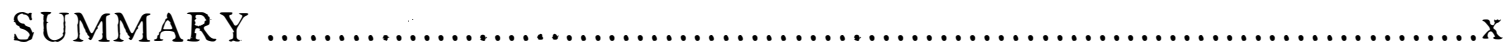

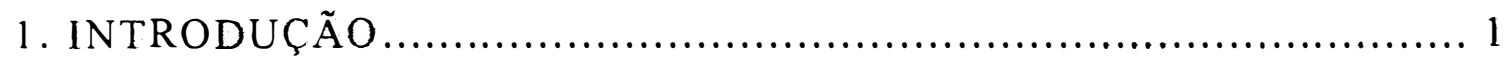

2. REVISÃO DE LITERATURA ............................................ 3

2.1. Microbiologia da Fermentação da Silagem............................. 3

2.2. Aditivos para Silagem............................................ 4

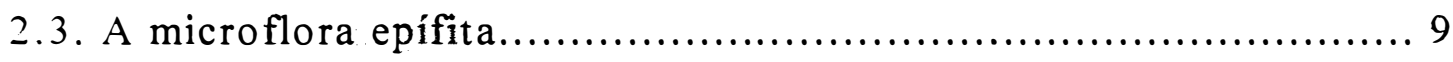

2.4. Nível de Inoculação .............................................. 14

2.5. Composição do Inoculante ............................................ 16

2.6. Substrato para Suprimento do Inóculo ...............................17

2.7. Métodos de Obtenção de Inoculantes Bacterianos para

Silagem.......................................................... 20

2.8. Qualidade da Silagem e Desempenho Animal......................22

3. MATERIAL E MÉTODOS ............................................ 26

3.1. Experimento I - Silagem com Alta Matéria Seca ...................27

3.1.1. Avaliação de Aditivo Bacteriano para Silagem sobre o Desempenho de Bovinos ............................27

3.1.2. Avaliação da Aditivação do Inoculante Bacteriano através da Digestibilidade "in vivo" em Ovinos............229

3.1.3. Avaliação da Aditivação do Inoculante Bacteriano quanto à Recuperação da MS da Silagem ................... 30 
3.1.4. Avaliação da Aditivação do Inoculante Bacteriano quanto ao Perfil da Fermentação de Silagem de Milho ....31

3.2. Experimento II- Silagens com Diferentes Teores de MS ............ 32

3.2.1. Avaliação da Aditivação do Inoculante Bacteriano sobre a Digestibilidade "in vivo" em Bovinos................33

3.2.2. Avaliação da Aditivação do Inoculante Bacteriano sobre a Degradabilidade "in situ" de Silagens Inoculadas..........34

3.2.3. Avaliação da Taxa de Passagem de Dietas à Base de Silagens Tratadas com Inóculos Bacterianos ............. 37

4. RESULTADOS E DISCUSS ÃO.......................................... 38

4.1. Experimento I- Silagem com Alta Matéria Seca .....................38

4.1.1. Avaliação de Aditivo Bacteriano para Silagem no

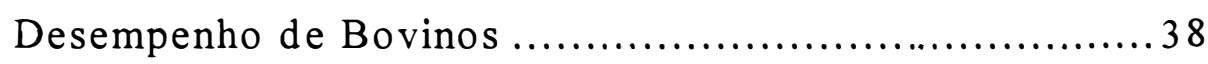

4.1.2. Avaliação da Aditivação do Inoculante Bacteriano na Digestibilidade "in vivo" em Ovinos ......................40

4.1.3. Efeito da Aditivação do Inoculante Bacteriano na Recuperação da Matéria Seca da Silagem de Milho.........43

4.1.4. Avaliação da Aditivação do Inoculante Bacteriano quanto ao Perfil de Fermentação de Silagem de Milho ....44

4.2. Experimento II- Silagens com Diferentes Níveis de MS 47

4.2.1. Avaliação da Aditivação do Inoculante Bacteriano sobre a Digestibilidade "in vivo" em Bovinos................50

4.2.2. Avaliação da Aditivação do Inoculante Bacteriano sobre a Taxa de Passagem de Dietas à Base de Silagem de Milho com Alta e Baixa MS, com e sem Inoculante ....54 
4.2.3. Avaliação da Aditivação do Inoculante Bacteriano na Degradabilidade "in situ" de Silagens Inoculadas .......55

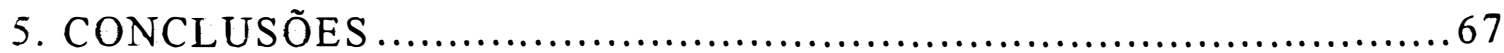

6. REFERÊNCIAS BIBLIOGRÁFICAS ................................... 68 


\section{AVALIAÇÃO DO EFEITO DE INOCULANTE BACTERIANO SOBRE A QUALIDADE DE SILAGEM E DESEMPENHO ANIMAL}

Autor: Jozivaldo Prudêncio Gomes de Morais

Orientador: Prof. Dr. Celso Boin

\section{RESUMO}

Os objetivos deste trabalho foram avaliar o efeito de inoculante bacteriano na qualidade de silagem de milho e no desempenho de bovinos da raça nelore. $\mathrm{O}$ trabalho foi dividido em duas fases: na primeira (experimento I), trabalhou-se com silagem com alta matéria seca (MS), em dois silos poço, inoculada e sem inoculação; e na segunda (experimento II),utilizaram-se 12 silos poço com silagem com alta e baixa MS, inoculada e não inoculada. No experimento I foram confinados 16 bovinos. nelore em baias individuais e divididos em duas dietas, uma à base de silagem inoculada e outra não inoculada (inteiramente casualisado). As dietas tinham $89,2 \%$ de silagem e $10,8 \%$ de concentrado (farelo de algodão, uréia e minerais). Foram analisados consumo de MS (Kg $\mathrm{MS} /$ animal/dia), consumo de MS em \% do peso vivo, consumo de MS em g/Kg PV, ganho de peso vivo diário (Kg/animal/dia) e conversão alimentar ( $\mathrm{Kg} \mathrm{MS} / \mathrm{Kg}$ ganho de peso). Não foram observadas diferenças estatísticamente significativas entre os tratamentos quanto aos parâmetros analisados $(\mathrm{P}>0,05)$. Foram colocados dentro de cada silo poço 4 sacos de plástico permeáveis, em diferentes profundidades para avaliar a recuperação da MS, proteína bruta, nitrogênio amoniacal e pH entre silagens inoculada e não inoculada. Não houve diferenças entre os tratamentos com relação aos parâmetros analisados $(\mathrm{P}>0,05)$. Foram confeccionados 24 mini-silos, distribuidos igualmente nos 
dois tratamentos (alta MS, com e sem inoculação), onde foi observado o $\mathrm{pH}$ na tendência temporal do processo fermentativo. Dois outros mini-silos, contendo silagem com alta MS, inoculada e não inoculada, tinham termômetros de bulbo de mercúrio inseridos no centro da massa ensilada para acompanhamento da temperatura $\left({ }^{\circ} \mathrm{C}\right) . \mathrm{O} \mathrm{pH}$ e a temperatura das silagens não diferiram entre os tratamentos $(P>0,05)$. Foi realizado ensaio de digestibiliade "in vivo" com 6 carneiros em quatro períodos de coleta (inteiramente casualisado), recebendo as mesmas dietas experimentais utilizadas no ensaio com bovinos, com 2 níveis de fornecimento: 45 e $65 \mathrm{~g} / \mathrm{Kg}$ de PV0,75. Não houve diferenças significativas entre tratamentos para digestibilidade do nitrogênio, da lignina e do extrato etéreo $(\mathrm{P}>0,05)$. Para silagem inoculada foi observado maior digestibilidade da fibra em detergente neutro (DFDN) quando fornecido níveis de $65 \mathrm{~g} / \mathrm{Kg}$ de $\mathrm{PV} 0,75 \mathrm{e}$ da fibra em detergente ácido (DFDA) para os dois níveis $(\mathrm{P}<0,1)$. A interação tratamento e nivel de ingestão foi significativa para DFDN e DFDA na silagem não inoculada $(\mathrm{P}<0,1)$.

No experimento II, foram realizados avaliações da digestibilidade "in vivo", degradabilidade "in situ" e determinação das taxas de passagem em bovinos. Os quatro tratamentos (alta MS inoculado, alta MS não inoculado, baixa MS inoculado, baixa MS não inoculado) a serem testados foram distribuidos em doze silos tipo poço. No ensaio de digestibilidade "in vivo" 8 bovinos nelore foram distribuidos nos 4 tipos de silagens, com 8 períodos de coletas (inteiramente casualisado com fatorial $4 \times 2$ ), sendo 4 períodos com fornecimento de $60 \mathrm{~g} / \mathrm{Kg} \mathrm{PV}^{0,75}$ e 4 períodos de $80 \mathrm{~g} / \mathrm{Kg}$ de $\mathrm{PV}^{0,75}$. Os parâmetros avaliados foram: digestibilidade da MS e dos componentes da MS (FDN, FDA, lignina, nitrogênio, nitrogênio insolúvel em detergente neutro- NIDN, nitrogênio insolúvel em detergente ácido- NIDA, extrato etéreo). Não foram observadas diferenças significativas entre os tratamentos e na interação tratamento e nivel de ingestão quanto aos parâmetros analisados $(P>0,05)$. Para o ensaio de degradabilidade "in situ" foram utilizados 3 bovinos nelore fistulados. Os animais foram submetidos aos 4 tratamentos, cada um recebendo $60 \mathrm{~g} / \mathrm{Kg}$ de $\mathrm{PV}^{0,75}$ por dia durante 4 períodos (blocos incompletos balanceados). Foram analisados os seguintes parâmetros: frações solúvel (A), 
potencialmente degradável (B) e indegradável (C), taxa de degradação (TD), degradabilidade efetiva (DE) e potencial (DP) da MS, proteína bruta (PB), FDN e NIDN nas silagens de milho. Foram também analisadas as frações A, B, C, TD, DE e DP para MS e PB do farelo de algodão utilizado nas dietas. De um modo geral, não foi observado tendência de superioridade das silagens inoculadas. As determinações das taxas de passagem da fase sólida, utilizando a técnica do cromo mordente foram realizadas no decorrer do ensaio de degradação, com os mesmos bovinos. No rúmen dos animais foi introduzido, via cânula, fibra de silagem marcada com óxido de cromo e através da coleta de fezes em diferentes horários procedeu-se a recuperação da mesma. Não foram observadas diferenças significativas entre as taxas de passagem das dietas à base de silagem de milho com alta e baixa MS, inoculada e não inoculada $(\mathrm{P}>0,05)$. 


\title{
EVALUATION OF BACTERIAL INOCULATION ON CORN SILAGE QUALITY AND ANIMAL PERFORMANCE.
}

\author{
Author: Jozivaldo Prudêncio Gomes de Morais \\ Adviser: Prof. Dr. Celso Boin
}

\section{SUMMARY}

The objectives of this work were to evaluate the effects of lactic acid bacteria inoculation on corn silage quality and on the performance of Nelore bullocks. Two experiments were carried out. In the first one, high dry matter corn silages were produced using pit and laboratory silos with and without bacterial inoculation. Eight Nelore bullocks were fed each type of silage balanced for protein and minerals (89.2 and 10.8\% of silage and concentrate, dry basis, respectively) on a completely randomized design. No significant differences were observed between silages for dry matter intake, liveweight gain and feed convertion ( $\mathrm{P}>0.05$ ). Dry matter loss during ensiling evaluated using four polyethilene bags burried at different depths in the silo were not different $(\mathrm{P}>0.05)$. No inoculation effects were also observed for protein, ammoniacal nitrogen and $\mathrm{pH}$ values $(\mathrm{P}>0.05)$. The time course variation of temperature and $\mathrm{pH}$ mensured in laboratory silos equipped with mercury bulb thermometer was similar for the two types of silage ( $\mathrm{P}>0.05$ ). In a digestion trial with lambs fed at two levels of intake (45 and $65 \mathrm{~g} / \mathrm{Kg}$ $\mathrm{BW}^{075}$ ), a significant interation $(\mathrm{P}<0.05)$ between sialge type vs level of intake. In de second experiment, corn forage at two levels of dry matter content was ensiled with and without bacterial inoculation. Eigth Nelore steers were used in a digestion trial replicated two times (eight observations per treatment). No differences among treatments were observed ( $\mathrm{P}>0.05)$ for dry matter, NDF, ADF, nitrogen and EE digestibility. In a "in situ" trial no differences $(\mathrm{P}>0.05)$ were observed among treatments for extent and rate degradation of dry matter, protein, NDF and NIND. The extent and rate of degradation of these fractions for cottonseed meal incubated in the rumen of animals fed the different silages were similar $(\mathrm{P}>0.05)$. Rate of passage measured using chromium oxide mordent fiber was not affected by treatment $(\mathrm{P}>0.05)$. 


\section{1- INTRODUÇÃO}

A região centro-sul do Brasil dispõe de estações do ano bem definidas, onde existe, em algumas épocas, grande abundância de pastos e forragens e, em outras, escassez. Tal sazonalidade é profundamente influenciada pelo regime pluviométrico e variação da temperatura. No entanto, a necessidade de forragem para os animais de uma propriedade é mais ou menos constante durante todo o ano.

A periodicidade das estações de produção leva a variação no desempenho animal, com épocas de grandes dificuldades para a manutenção do ganho de peso e produção de leite. Para contornar esse problema, uma das técnicas frequentemente adotada é a ensilagem. Esta forma de conservação tem alguns inconvenientes relacionados com seu valor nutritivo, técnicas de confecção e custo.

A produção de silagem é dependente de fermentações anaeróbicas que envolvem várias espécies de bactérias epífitas. Neste grupo, as bactérias produtoras de ácido lático contribuem para a preservação da silagem através da produção desse e de outros ácidos orgânicos. $\mathrm{O}$ acúmulo de lactato reduz o $\mathrm{pH}$ da silagem, que é inibidor da atividade microbiana indesejável e também resulta na dominância de lactobacilus e pediococus. A presença de quantidades elevadas de ácido lático na silagem geralmente aumenta a eficiência de preservação da mesma. Fermentações indesejáveis provocadas, principalmente, por bactérias do grupo clostrídia, aumentam as perdas da matéria seca e 
reduzem a qualidade nutricional da silagem. Portanto, uma inoculação adicional de bactérias no momento da ensilagem poderia aumentar a produção de lactato, diminuir a perda do material ensilado e contribuir para o aumento do desempenho animal.

Ultimamente existe grande interesse comercial de selecionar estirpes de bactérais láticas que possam interferir favoravelmente no processo fermentativo natural. No entanto, o efeito dos inoculantes bacterianos como aditivos de silagem tem sido variável e diversas pesquisas foram incapazes de levar a um entendimento claro da sua eficiência. Nesse sentido, o conhecimento de dados sobre o desempenho animal e a qualidade de silagem tropical tratada com inoculante podem fornecer mais subsídios para a utilização na prática de inóculos comercialmente disponíveis no Brasil.

O presente trabalho teve como objetivo avaliar o efeito da silagem inoculada sobre o desempenho de animais em confinamento, digestibilidade "in vivo" com bovinos e carneiros, taxas de degradação e parâmetros de fermentação de silagem de milho. 


\section{REVISÃO DE LITERATURA}

\subsection{Microbiologia da Fermentação da Silagem}

O objetivo básico da ensilagem é preservar a forragem com o minimo de perdas de nutrientes para que o animal possa receber alimentação com a composição próxima à da original. A essência do processo é promover rápida fermentação lática oriunda de bactérias predominantemente homofermentativas sob condições anaeróbicas, as quais ocorrem naturalmente (MERRY et al., 1993). Infelizmente, as bactérias láticas não são os únicos microorganismos que ocorrem nas silagens. Inúmeros microorganismos indesejáveis como enterobactérias e clostrídios podem competir com as bactérias láticas pelos mesmos substratos, dependendo das condições encontradas no silo. Além disso, as bactérias láticas são divididas em dois grandes grupos que diferem quanto à produção de lactato a partir de açúcares. As homofermentativas produzem ácido lático a partir de glucose e frutose, sem perda de MS, enquanto as heterofermentativas produzem ácido lático e também outros produtos tais como $\mathrm{CO}_{2}$, etanol e ácido acético, que levam a perdas de MS e são menos efícientes no abaixamento do pH (McDONALD et al., 1991).

Há muito vem sendo estudada a presença de bactérias na parte aérea da planta a ser ensilada e tem-se constatado que a maioria é aeróbia 
estrita que contribue pouco ou nada para o processo de fermentação da silagem. Dentre os organismos capazes de realizar fermentação anaeróbia encontrados antes do processo de ensilagem, destacam-se pela sua abundância os membros da família das Enterobacteriaceae e espécies de Bacillus e Clostridium, sendo que as últimas são encontradas em menor frequência e sua contaminação parece ocorrer a partir do solo (McDONALD et al., 1991). As enterobactérias e clotrídios são considerados por ter efeito negativo no processo de fermentação, enquanto as leveduras, bolores e bacilos contribuem para deterioração aeróbica da silagem (WOOLFORD, 1984). As forragens para ensilagem usualmente contêm altos níveis de enterobactérias que aumentam durante os primeiros dias de ensilagem, mas decrescem rapidamente com o decorrer da fermentação (LINDGREN et al., 1985)

As bactérias produtoras de ácido lático, principais organismos no processo de fermentação da silagem, são encontradas em pouca quantidade no vegetal. Dellaglio (1985), citado por McDONALD et al. (1991), afirmou que elas estão usualmente presentes em gramineas em quantidade 100 vezes menor do que outros grupos como fungos e enterobactérias.

\subsection{Aditivos para silagem}

Os três principais fatores que afetam o processo de ensilagem são matéria seca, concentração de carboidratos solúveis e poder tampão da forragem. Um material ideal para ensilagem deve ter alto conteúdo de matéria seca, alta concentração de carboidratos solúveis e baixo poder tampão. Geralmente, as leguminosas possuem baixa concentração de carboidratos solúveis, as gramíneas apresentam concentração intermediária 
e no milho ocorre concentração mais alta. O poder tampão é mais alto em leguminosas, intermediário em gramíneas e mais baixo no milho. Para obtenção de níveis ideais desses fatores é necessário a execução correta de medidas que vão desde o plantio até o momento da descarga no silo.

Causas ambientais, econômicas e técnicas podem afetar o potencial de produção e qualidade da silagem. A ocorrência de chuvas no momento do corte da forragem, por exemplo, altera o ponto ideal de matéria seca. Silos construídos inadequadamente podem contribuir para um difícil estabelecimento de condições anaeróbias.

A adição de produtos externos ao processo de ensilagem surgiu como forma de melhorar o resultado final da fermentação, alterando a matéria seca, carboidratos solúveis e/ou diminuindo o $\mathrm{pH}$ do material ensilado.

Segundo McDONALD et al. (1991) os aditivos para silagem podem ser classificados em 5 categorias principais: estimulantes da fermentação, que agem através da adição de culturas bacterianas ou fontes de carboidratos; inibidores da fermentação, que agem inibindo parcial ou totalmente a fermentação; inibidores da deteriorização aeróbica, que agem principalmente controlando a deteriorização da silagem em exposição ao ar; nutrientes, que são adicionados ao material para melhorar o valor nutricional da silagem, e absorventes, que são adicionados, principalmente, à forragens com baixa MS para reduzir perdas de nutrientes por efluentes e diminuir a poluição.

No ano de 1938, A. I. Virtanen conduziu na Finlândia estudos sobre a aplicação de ácidos minerais na produção de silagem, o que the valeu o Prêmio Nobel de 1945 (VAN SOEST, 1982). Desde então as 
silagens tratadas com ácidos minerais passaram a ser conhecidas como AIV, iniciais de seu primeiro estudioso.

Daí em diante surgiram vários métodos, formas e produtos de preservação. Mann (1975), em revisão de WOOLFORD (1984), enumerou 178 produtos testados ou simplesmente surgidos no mercado entre os anos de 1949 e 1970, sendo que nos últimos anos esta lista tem se ampliado rapidamente.

Falhas nas legislações governamentais de diversos países têm permitido a entrada no mercado de produtos não devidamente testados. Tanto que o efeito atribuído a muitos produtos usados comercialmente como aditivos é de certa forma exagerada. Por outro lado, a falta de informações técnicas confiáveis sobre o produto leva o produtor à substituição de boas técnicas de manejo do silo por aditivos, o que certamente resulta numa diminuição da qualidade do produto ensilado.

A meta é encontrar um produto economicamente viável que assegure uma preservação eficiente desde o momento de abertura do silo até sua completa utilização. WOOLFORD (1984), no entanto, afirma que este objetivo ainda não tinha sido atingido.

Historicamente, os aditivos foram usados para melhorar o padrão fermentativo de silagens produzidas sob difíceis condições (MERRY et al., 1993). Para VAN SOEST (1982), o uso de aditivos têm dois principais propósitos: influenciar o curso da fermentação e/ou alterar a composição do material ensilado promovendo melhor valor nutritivo.

A quantidade do produto a ser adicionado pode variar em função do total de carboidratos disponíveis no material a ser ensilado. De acordo com Wilkinson et al (1983), citados por VAN VUUREN et al (1989), uma 
forragem para produzir silagem bem preservada deverá conter um mínimo de $2 \%$ de carboidratos solúveis na matéria fresca.

O precursor dos estudos com ácidos como aditivos, Virtanen, determinou a quantidade necessária de ácido para baixar o $\mathrm{pH}$ a um nível, no qual as enzimas, tanto da planta como de microorganismos, fossem inibidas (McDONALD et al., 1991). Com o pH próximo de 3 garantir-seiam condições para evitar, por exemplo, a transformação da proteina em compostos nitrogenados não protéicos. O problema é que o rápido abaixamento do $\mathrm{pH}$ muitas vezes depende de altas concentrações de ácido, o que torna a silagem impalatável aos animais.

O conceito de inóculo para ensilagem a partir de estirpes selecionadas de bactérias láticas homofermentativas como uma prática comercial data do início da década de 80 (MERRY et al., 1993). No entanto, a idéia de bactéria como aditivo é mais antiga. Whittenbury (1961) citado por McDONALD et al. (1991), estabeleceu critérios para a utilização de bactérias como aditivos para silagens que posteriormente foram complementados por Wieringa e Beck (1965), também citados pelos mesmos autores.

Os estágios iniciais de ensilagem são criticos para o êxito da fermentação, pois as atividades enzimáticas da planta ainda continuam e grande número de enterobactérias podem estar fermentando açúcares solúveis. Os inoculantes são colocados para restingir essas atividades indesejáveis, devendo conter número suficiente de bactérias homofermentativas viáveis, que possam rapidamente dominar a microflora natural. Para MERRY et al. (1993), o sucesso do processo depende da habilidade dessas bactérias adicionadas para crescimento rápido e uso dos nutrientes disponíveis na forragem. Assim, se o ácido lático poder ser 
produzido em velocidade suficiente irá reduzir o nível de atividades adversas provocadas pelos microoganismos indesejáveis.

Diversos trabalhos foram conduzidos sem, no entanto, mostrarem resultados que justificassem em definitivo o uso das bactérias como aditivos. ANDERSON et al. (1989) afirmaram que o desempenho de bactérias como aditivos tem sido variável e que o maior problema encontrado está em relacionar o sucesso obtido em silos de laboratório com a eficácia de sua aplicação no campo. Os trabalhos de LUTHER (1986) indicaram que o inoculante não melhorou os valores de $\mathrm{pH}$, nitrogênio amoniacal $\left(\mathrm{N}-\mathrm{NH}_{3}\right)$ e ácidos graxos voláteis, em silos grandes. Em ensaios utilizando animais foi encontrada maior digestibilidade da MS, porém menor eficiência de ganho diário para silagens tratadas. E mesmo em silos de laboratório nem sempre os resultados são promissores. WOOLFORD \& SAWCZYC (1984b) verificaram que a aplicação de bactérias na ensilagem não teve influência alguma sobre o desenvolvimento de bactérias no silo e na acidificação ou promoção da fermentação homolática, quando comparadas com silagem tratada com ácido fórmico. SCHAEFER et al. (1989), testando inóculos em silagens de milho na alimentação de novilhos em crescimento e terminação, constataram que a eficiência de conversão alimentar não foi afetada pelos tratamentos.

Apesar das contradições, o número de inóculos aumentou sensivelmente nos últimos anos. Wilkinson (1990), citado por MERRY et al. (1993), afirmou que $67 \%$ dos aditivos disponíveis comercialmente na Inglaterra eram à base de estirpes de bactérias.

Nos ultimos anos tem ocorrido melhora nos produtos comercialmente disponíveis (WEDDEL \& YACKIMINIE, 1987), pois o processo de obtenção de estirpes puras em larga escala foi facilitado por 
novos métodos de secagem a frio ("freeze-dried") conforme McDONALD et al., 1991.

\section{3.- A microflora epífita}

Após a ensilagem, os microorganismos capazes de crescimento anaeróbio, tais como bactérias láticas, enterobactéria, clostridia, algumas espécies de bacilos e leveduras começam a se desenvolver e competir por nutrientes (McDONALD et al., 1991)

Mudanças no número e populações de microflora epífita produtora de ácido lático ocorrem durante o processo de fermentação da silagem (WOOLFORD, 1984). Um fator preponderante para o início e êxito da fermentação, tanto na presença como ausência de inoculante, é a composição desta microflora. Segundo LIN et al. (1992), a quantidade de bactérias láticas epífitas é usualmente baixa no momento da ensilagem, aumentando durante o corte.

MERRY et al. (1993) sumarizaram vários trabalhos sobre quantidades de microoganismos no material ensilado ( Tabela 1 ). Os autores mostram grande variação no número de bactérias viáveis nos mais diferentes materiais ensilados.

Em alguns ensaios é relacionado também o número relativo de espécies hetero e homofermentativas e nestes, frequentemente, a proporção de heteroláticas é igual ou maior do que as homoláticas. Desta forma, mesmo se o número de bactérias láticas for alto, elas podem não ser dos tipos mais apropriados ou ter taxa mais alta de crescimento de modo a dominar o processo fermentativo. Logo, o número de bactérias 


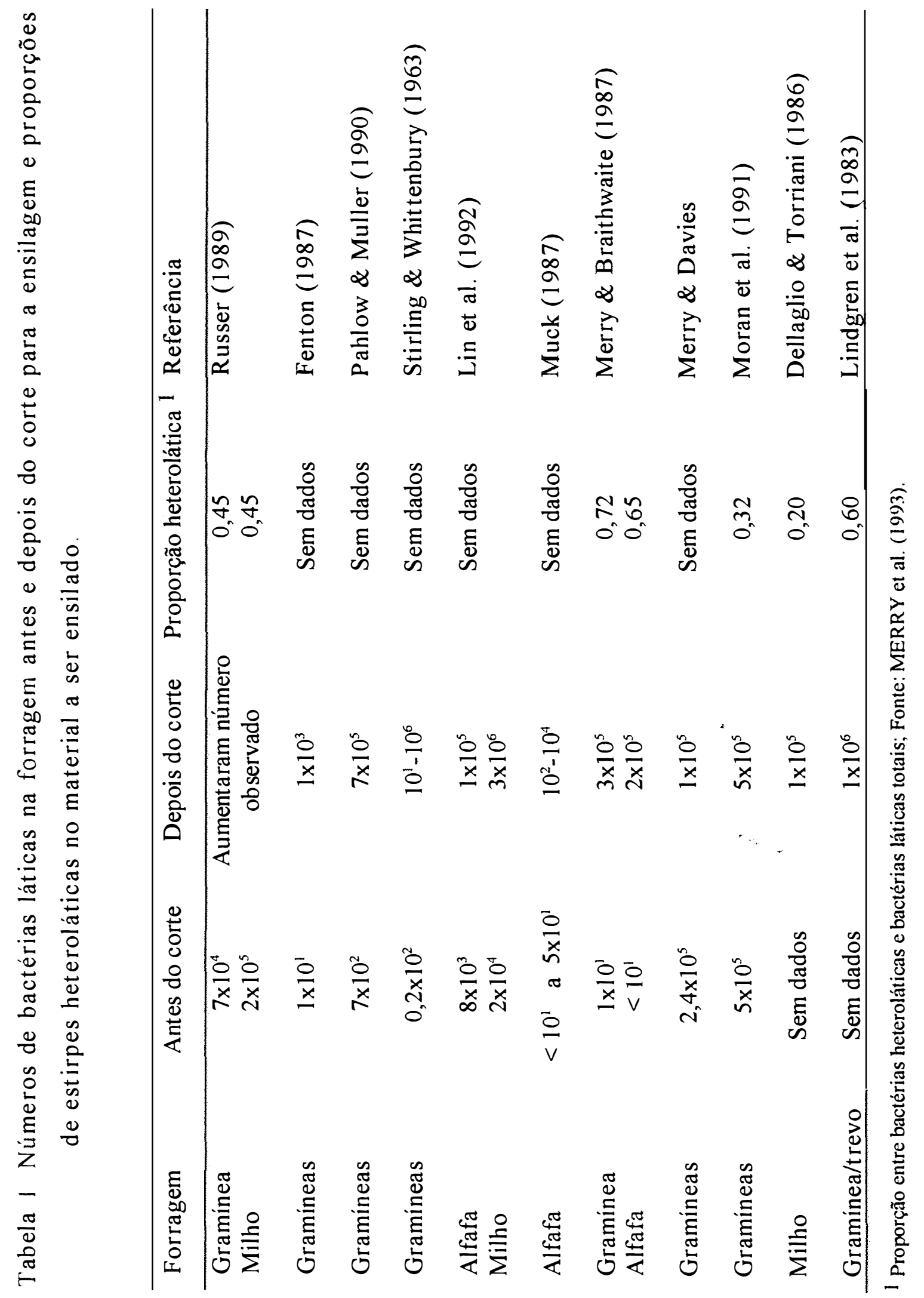


nem sempre prediz a eficiência do processo. Bolsen et al. (1989), citados por LIN et al.(1992), resumiram resultados de uma ampla faixa de materiais e condições de ensilagem, e concluíram que a contagem de bacterias epífitas produtoras de ácido lático nem sempre prediz a taxa ou eficiência da fermentação natural em silagem e que estas espécies ou estirpes e suas características no ambiente da silagem necessitam de uma descrição mais detalhada. Os mesmos autores investigaram a sucessão das bactérias láticas durante a pré e pós ensilagem tanto para alfafa como para milho e observaram que as espécies destes microorganismos variam entre milho e alfafa e também durante os períodos de pré e pós ensilagem. Eles concluíram que o conhecimento dos números e espécies de microfloras epífitas não são suficientes para predizer o processo de fermentação.

A grande variação no número de bactérias láticas no material a ser ensilado pode ser atribuida a diversos fatores tais como temperatura, radiação ultravioleta, umidade relativa e fatores associadọs com a própria forragem ( Moran et al., 1991, citado por MERRY et al., 1993). McDONALD et al. (1991) acreditam que o acúmulo e multiplicação de bactérias nas superfícies das máquinas de corte durante o processo de colheita serve como inoculante para materiais recém cortados advindos do campo. FENTON (1987) e MUCK (1990) admitem que a teoria da inoculação natural da forragem através de maquinárias usadas no corte da mesma justifica o grande aumento das bactérias láticas durante a colheita e nos estágios iniciais de ensilagem. Mas, segundo MERRY et al. (1993) o aumento drástico do número de bactérias epífitas constante na Tabela 1, não pode ser explicado somente através do crescimento microbiano. Uma hipótese proposta por Pahlow (1991), citado por MERRY et al (1993), tenta explicar parcialmente estas observações na silagem. Ele sugeriu que em resposta às condições desfavoráveis na superfície intacta da planta, tais como radiação ultra-violeta, calor, ausência de umidade, ausência de 
nutrientes ou a própria presença de oxigênio, as bactérias epífitas têm desenvolvido estratégias de sobrevivência similares ao estado "somnicell" descrito por ROSZAK \& COLWELL (1987). Esses autores propuseram que em ambientes naturais existe uma proporção de bactérias viáveis que não possuem habilidade para multiplicação em meios de cultura. Essa proporção de microorganismos dormentes, particulamente lactobacilus, restabelecem suas condições de crescimento em função de uma influência específica exibida no processo de colheita, tais como liberação de enzimas, minerais, etc. a partir do material da planta

Tem sido sugerido que as bactérias responsáveis pelo processo de fermentação de silagens tropicais podem ser diferentes daquelas encontradas em silagens de origem temperada (CATCHPOOLE \& HENZEL, 1971). AGUILERA (1975), trabalhando com a ensilagem de capim elefante mostrou que o mesmo pode ser bem ensilado tendo altas quantidades de ácido acético como principal ácido conseryante da silagem. TJANDRAATMAJA et al. (1990) isolaram e caracterizaram bactérias láticas de forragens tropicais (milho e sorgo), antes e durante a ensilagem, e encontraram que mais de $50 \%$ dos ácidos produzidos no material ensilado era lático, indicando que o processo fermentativo foi realizado principalmente por bactérias produtoras desse ácido. Estes últimos resultados indicam que em silagens de forragens tropicais, igualmente como ocorre em forragens temperadas, o ácido lático é o principal responsável pelo processo de fermentação.

Um dos principais grupos de microorganismos competindo com as bactérias láticas nos estágios iniciais da fermentação da silagem são as enterobactérias. Elas têm efeito negativo sobre o processo de fermentação, não contribuindo efetivamente para a queda do $\mathrm{pH}$, produzindo endotoxinas e estando implicadas na deaminação de aminoácidos 
(MCDONALD et al., 1991). O material ensilado usualmente contém altos niveis de enterobactérias ( $>10^{5} / \mathrm{g}$ do peso fresco) que crescem rapidamente durante as primeiras horas de fermentação devido ao elevado $\mathrm{pH}$ e baixas concentrações de ácido lático, decrescendo no decorrer do processo (OSTLING \& LINDGREN, 1991). Por isso seu número no interior de um silo pode ser considerado um bom indicador de rápido declínio de $\mathrm{pH}$ e de boa atividade de um dado inoculante. OSTLING \& LINDGREN (1995), medindo a influência da enterobacteria na fermentação e estabilidade aeróbica de silagens de gramíneas encontraram efeitos positivos e negativos. Foi observado maior produção de $\mathrm{N}$-amoniacal e dos ácidos acético e lático e uma inesperada maior estabilidade aeróbica para silagens inoculadas com enterobactérias.

Quando gramíneas são ensiladas com alta umidade, baixas concentrações de carboidratos solúveis para fermentação e número elevado de bactérias competidoras, especialmente as enterobactérias, ocorre redução nas mudanças sucessivas das bactérias láticas epífitas(McDONALD et al., 1991).

Pahlow \& Muller (1990), citados por MERRY et al. (1993), afirmaram que sob algumas condições, parte da população enterobacteriana poderia estar em estado "não culturável" e assim sujeita a uma subestimação similar à aquela discutida para as bactérias láticas. Segundo OSTLING \& LINDGREN (1991), as sobras de forragem não ensilada nas fazendas são ricas fontes de enterobactérias, e sua existência contribui para a contaminação do material a ser ainda ensilado. 


\subsection{Nível de inoculação}

Devido à ampla variação no número de bactérias láticas vista na forragem a ser ensilada sob diversas condições, muitas discussões têm ocorrido sobre o nível de inoculação que deveria ser utilizado. Segundo LUTHER (1986), a inoculação microbiana de qualquer material forrageiro deveria ser benéfica quando colonias viáveis de bactérias epífitas são limitadas.

SEALE (1986) propôs um mínimo de $10^{5}$ unidade formadora de colonia (UFC) por grama de forragem fresca e um nível preferível de $10^{6}$. De acordo com MERRY et al. (1993) apesar de haver pouca informação definitiva sobre níveis de inoculação a taxa de aplicação de $10^{6}$ tem sido geralmente bem aceita.

HERON et al. (1986) observaram as mudanças no processo fermentativo de azevém em silos de laboratório inoculados com $L$. plantarum a taxas de aplicação de $10^{4}, 10^{6}$ e $10^{8} \mathrm{UFC} / \mathrm{g}$ de forragem fresca. Houve maior declínio do $\mathrm{pH}$, do desaparecimento dos carboidratos solúveis e aumento das concentrações de ácido lático com o aumento da inoculação o que indicou maior fermentação homolática. O rápido declínio do $\mathrm{pH}$ causado pela inoculação de $10^{6}$ e $10^{8} \mathrm{UFC} / \mathrm{g}$ reduziu o nível de proteólise, mas não houve vantagem na adição de mais de $10^{6} \mathrm{UFC} / \mathrm{g}$ de forragem fresca. Estes dados demonstram claramente o princípio da inoculação e o efeito da quantidade do inóculo, mas não fizeram referência à quantidade da microflora epífita.

Os dados microbiológicos obtidos por PAHLOW (1990) introduziram o conceito de "fator de inoculação" (FI), que é razão entre o número de bactérias láticas no material tratado sobre o número de 
bactérias láticas no material não tratado. Muitos dos dados foram obtidos a partir de trabalhos com gramíneas ou milho no momento da ensilagem e estes indicaram que bactérias láticas abaixo de $10^{3} \mathrm{UFC} / \mathrm{g}$ de forragem fresca foram uma exceção e que em $75 \%$ dos experimentos variaram de $10^{4}-10^{6} \mathrm{UFC} / \mathrm{g}$ de forragem fresca. O autor calculou os valores de FI e relacionou-os com mudanças ocorridas nos parâmetros fermentativos das silagens com baixo, médio e alto número de bactéria lática epífita (Tabela 2).

Tabela 2 Efeito da inoculação na população de bactérias do ácido lático em forragens com teores de carboidratos solúveis de $15 \mathrm{~g} / \mathrm{Kg}$ de forragem fresca.

\begin{tabular}{|c|c|c|c|c|c|c|}
\hline \multicolumn{2}{|c|}{$\begin{array}{l}\text { Número de bactérias } \\
\text { láticas na forragem }\end{array}$} & \multirow[t]{2}{*}{$\begin{array}{c}\text { Fator de } \\
\text { inoculação }\end{array}$} & \multirow[t]{2}{*}{$\begin{array}{l}\text { Número de } \\
\text { ensaios }\end{array}$} & \multicolumn{3}{|c|}{$\begin{array}{c}\text { Mudanças na qualidade em relação } \\
\text { ao controle }(100)\end{array}$} \\
\hline Epifita & Inoculada & & & A. lático & A. acético & Amônia \\
\hline $1 \times 10^{2}$ & $3 \times 10^{4}$ & $>10$ & 41 & 186 & 77 & 79 \\
\hline $4 \times 10^{4}$ & $3 \times 10^{5}$ & $2-10$ & 18 & 128 & 80 & 90 \\
\hline $73 \times 10^{5}$ & $1^{*}$ & $>2$ & 15 & 102 & 87. & 96 \\
\hline
\end{tabular}

As taxas de inoculação foram relativamente baixas em todos os ensaios, mas ficou claro que existiu relação positiva entre valor de FI e qualidade da silagem. Para FI acima de 10 as concentrações de ácido lático dobraram em relação a silagem não tratada. Já as concentrações de ácido acético oriundas de fermentações heteroláticas e as concentrações de $\mathrm{N}$-amoniacal derivadas da atividade proteolítica na massa ensilada decresceram. $\mathrm{O}$ autor concluiu que para se obter FI igual a 10 na maioria das situações faz-se necessária uma taxa de inoculação de $10^{6} \mathrm{UFC} / \mathrm{g}$ de forragem fresca. 


\subsection{Composição do inoculante}

Tão importante para o sucesso da inoculação quanto a quantidade de microorganismos inoculantes é a composição microbiana do inóculo a ser adicionado à silagem. O critério de seleção de bactérias láticas para adição ao material a ser ensilado de modo que elas possam dominar a fermentação e produzir rápida e eficiente acidificação natural foi primeiramente proposto por Whittenbury em 1961 e complementado por Wieringa e Beck (1964), citados por McDONALD et al., 1991.

WOOLFORD \& SAWCZYC (1984a) estudaram 21 estirpes de bactérias visando selecioná-las para uso como inoculante. Dentre os critérios estabelecidos estavam competitividade entre espécies por substrato, resistência a altas temperaturas, habilidade para efetuar rápida acidificação e atingir baixo $\mathrm{pH}$, capacidade para produzir ácidos a partir de açúcar e sua ação contra ácidos orgânicos encontrados na forragem. Foi observado também tolerância à acidez e à disponibilidade de umidade no material. Nenhuma das culturas estudadas satisfez os critérios de seleção. Contudo, três estirpes (Streptococcus durans, Lactobacillus acidophilus e Lactobacillus plantarum ) tiveram maior potencial do que as demais. Os microorganismos heterofermentativos foram imediatamente excluídos. Para os autores, mistura de inóculos de gêneros diferentes pode fornecer melhores resultados do que cultura pura. Após o processo de seleção WOOLFORD \& SAWCZYC (1984b), usaram as melhores estirpes como inoculante em silos de laboratório. Nenhuma das culturas ou misturas de culturas foi efeciente na taxa de acidificação ou promoção da fermentação homolática, tanto em altas como em baixas taxas de aplicação $\left(10^{6}\right.$ vs. $10^{3} \mathrm{~g} / \mathrm{Kg}$ de $\mathrm{MS}$ da forragem, respectivamente). 
O Lactobacillus plantarum, ainda que de difícil conservação, tem sido considerado como uma das bactérias mais adequadas para o processo de inoculação pelos critérios de . Whittenbury (PAHLOW, 1990). Contudo, o próprio Whittenbury (1961) citado por MERRY et al (1993), considerou $L$. plantarum de pouca eficiência na produção de ácido lático enquanto o pH não atingir valores inferiores a 5 .

De acordo com LISSETE et al. (1992) a menor efetividade de $L$. plantarum pode ser atribuída a sua fase longa de latência, que retarda 0 início da fermentação, ao efeito que pode sofrer da pressão osmótica e sua dificuldade em produzir ácido lático em faixas de $\mathrm{pH}$ acima de 5. Bryan Jones (1969), citado por McDONALD et al (1991), sugeriu uma, combinação de Streptococcus (Enterococcus) faecalis com L. plantarum onde o primeiro atuaria em faixas de $\mathrm{pH}$ mais elevadas no início do processo de ensilagem e o segundo quando o $\mathrm{pH}$ estivesse abaixo de 5 . Este princípio tem sido usado em muitos inoculantes disponíveis atualmente no mercado onde se utiliza uma mistura de bactérias tais como Pediococcus ou Streptococcus combinados com Lactobacillus homofermentativyos. Os pediococos são ativos sobre uma ampla faixa de $\mathrm{pH}$ e têm sido frequentemente encontrados predominando nos estágios iniciais da ensilagem (FITZSIMMONS et al., 1992).

\subsection{Substrato para suprimento do inóculo}

O suprimento alimentar do inóculo é um dos principais fatores que influenciam sobre a fermentação. Mesmo uma das mais apropriadas estirpes de bactérias láticas não pode ser eficiente se não houver na massa ensilada disponibilidade de carboidratos solúveis em água ( $\mathrm{CHO}$-sol). 
De acordo com VAN SOEST (1982), os CHO-sol podem ser classificados como monossacarídeos, oligossacarídeos e alguns polissacarídeos. Uma série de fatores pode influenciar sobre a quantidade de CHO-sol numa planta, tais como origem das espécies (tropical ou temperada), cultivar, estágio de crescimento, variações diurnas, clima e níveis de fertilizações (McDONALD et al., 1991). A concentração total desses açúcares na planta pode variar de 5 a $300 \mathrm{~g} / \mathrm{kg}$ de forragem fresca (HENDERSON \& McDONALD, 1971). Como resultado desta ampla variação tem havido interesse considerável em se adequar quantidades de açúcares para promover fermentação desejável.

MERRY et al. (1993) citaram os estudos de Wilkinson et al. (1981) do início da década, antes da ampla difusão de aditivos bacterianos no mundo, nos quais eles estudaram 231 silagens de gramíneas, leguminosas e milho onde nenhum aditivo tinha sido usado. Eles verificaram que a quantidade crítica de CHO-sol para um bom processo de fermentação foi em torno de $20 \mathrm{~g} / \mathrm{Kg}$ de forragem fresca para condições experimentais e um limite de $30 \mathrm{~g} / \mathrm{Kg}$ de forragem fresca para condições práticas. Com o uso do inoculante poderia ser esperado menor exigência de CHO-sol, pois ocorreria maior efíciência de conversão de CHO-sol em lactato.

PATTERSON \& LINDGREN (1990) examinaram o efeito da concentração de açúcar e do uso de aditivos sobre a qualidade de silagem numa série de ensaios em silos de laboratório. A concentração de acúcar foi manipulada pela variação na proporção de gramíneas/leguminosas. Foram ensiladas silagens sem tratamento e tratadas com ácido fórmico por um período de mais de 60 dias e analisados parâmetros indicativos da qualidade da silagem tais como $\mathrm{pH}$, amônia e ácido lático. Nas silagens não inoculadas foi necessário em torno de $25 \mathrm{~g}$ de $\mathrm{CHO}$-sol/ $\mathrm{Kg}$ de forragem 
fresca para se obter produto de boa qualidade $(\mathrm{pH}<4,2$ e $\mathrm{N}$-amoniacal< $80 \mathrm{~g} / \mathrm{Kg}$ de forragem fresca), enquanto que a quantia correspondente para silagem inoculada foi de $20 \mathrm{~g}$ de $\mathrm{CHO}-\mathrm{sol} / \mathrm{Kg}$ de forragem fresca. Estes dados demonstram que o efeito da concentração de açúcar não foi tão importante na qualidade da silagem aditivada quanto na silagem sem tratamento, demonstrando menor exigência de CHO-sol para silagens inoculadas.

Um outro fator que merece consideração é a disponibilidade de CHO-sol no material ensilado. JONES et al. (1992) citam que a resposta limitada a altas taxas de inoculação nas características finais de um material ensilado pode ser devido à disponibilidade insuficiente de substrato. Esta disponibilidade é aumentada pela ação do corte e esmagamento com a consequente liberação do suco celular. Ocorre também na massa ensilada uma série de hidrólises ácidas que promovem a transformação de polissacarídeos em açúrares menos complexos. No entanto, dentre estes açúcares (glucose, frutose e sacarose), alguns tal como a frutose, podem encontrar-se em formas pouco disponiveis para as bactérias, de modo que nem todos os microorganismos produtores de ácido lático são capazes de aproveitá-los.

Buscando aumentar a disponibilidade de substrato na massa ensilada, passou-se a adicionar enzimas com o objetivo de provocar o rompimento de ligações de polissacarídeos indisponíveis para microorganismos produtores de ácido lático, causando aumento de açúcares fermentáveis para a microflora da silagem e maior digestibilidade da matéria orgânica (SETALA, 1989).

HENDERSON \& McDONALD (1977) conduziram uma série de experimentos em silos de laboratório para observar o efeito da celulase obtida a partir de Aspergillus niger em diferentes níveis. No primeiro 
experimento a celulase foi comparada a uma série de outros produtos como ácido fórmico, ácido capróico, formalina e metassulfito de sódio. Os resultados são indicadores de que menor conteúdo de celulose e maior quantidade de carboidrato solúvel foram encontrados nas silagens tratadas com ácido fórmico e celulase. No segundo experimento dos mesmos autores foram usados dois níveis de enzimas em esquema de interação com o ácido fórmico e analisados os mesmos parâmetros. Os dados demonstraram que a quantidade de celulose e celulase foram inversamente proporcionais. Os autores sugerem que as enzimas poderão ser combinadas com outro aditivo que propicie o abaixamento do $\mathrm{pH}$ a níveis considerados ótimos para a atividade celulolítica. A conversão da celulose nestes casos proporcionaria grande disponibilidade de carboidratos solúveis para o animal, uma vez que o ácido fórmico não permitiria o aproveitamento deste produto na fermentação.

De acordo com SETALA (1989), a adição de enzimas no momento da ensilagem pode provocar desintegração da parede celular, causando aumento da taxa de degradação no rúmen, resultando em maior digestibilidade e valor nutritivo.

\subsection{Métodos de obtenção de inoculantes bacteranos para silagem}

A exploração de inoculantes para silagem a nível comercial teve um grande impulso com a implementação do método de secagem a frio ("freeze-dried") de bactérias láticas, aumentando assim a facilidade de manuseio e o tempo de estocagem de bactérias viáveis (McDONALD et al. 1991). 
Contudo, apesar de quase todos os inoculantes disponiveis serem secos a frio, para MERRY et al. (1990), o método de coleta durante o ciclo de crescimento, a desidratação e a baixa temperatura induzem efeitos negativos no estado metabólico das bactérias. Esses autores inocularam uma parte de azevém ( $20 \% \mathrm{MS}, 170 \mathrm{~g}$ de $\mathrm{CHO}-$ sol/ $\mathrm{Kg}$ de $\mathrm{MS}$ ) com estirpes de $L$. plantarum que tinham sido submetidas a secagem a frio e uma outra parte com estirpes adicionadas a um meio de cultura por $18 \mathrm{~h}$. As taxas de inoculação foram ajustadas para atender uma quantidade de $10^{6}$ UFC de bactérias láticas/g de forragem fresca para ambos os tratamentos. Foram incluídos também dois outros tratamentos, um sem aditivos e outro com aplicação de ácido fórmico (31/ton). As taxas de produção de ácido lático e o declínio do $\mathrm{pH}$ foram mais efetivos para a cultura fresca do que para culturas secas e microflora natural da silagem controle. $\mathrm{O}$ ácido fórmico reduziu o pH imediatamente para a faixa de 5, mas a fermentação subsequente foi restringida devido a inibição das bactérias láticas. A queda mais rápida do $\mathrm{pH}$ para silagens inoculadas com culturas frescas teve maior impacto na população enterobacteriana que praticamente desapareceu após 5,5 dias de ensilagem.

MERRY et al. (1995), ainda comparando o efeito de culturas secas a frio com fresca verificaram que a principal vantagem da cultura fresca em relação à seca, quando adicionadas à forragem, foi proporcionada devido ao seu estado metabólico. Porém, ainda que a produção de inoculantes bacterianos pelo processo de secagem a frio exija grande demanda energética e seja de alto custo, é o processo mais conveniente em termos de longevidade, distribuição e manuseio seguro do produto. Nos trabalhos de NESBAKKEN \& BROCH-DUE (1991) com o uso de múltiplas estirpes de bactérias não foram obtidas diferenças entre culturas frescas e secas a frio em relação a perda por efluente, $\mathrm{pH}$ e níveis de carboidratos solúveis. 
Segundo MERRY et al. (1993) existe, atualmente, grande interesse na Inglaterra em se produzir inoculantes dentro do mesmo sistema de produção de iogurtes. Esta nova tecnologia visa desenvolver estirpes em processos mais simples, aumentando a atividade do inoculante e diminuindo o custo de produção.

\subsection{Qualidade da silagem e desempenho animal}

Ultimamente um dos principais critérios para avaliação da qualidade de silagem tem sido sua composição química e o efeito desta sobre o desempenho animal.

Grande parte das silagens produzidas é ensilada com baixo conteúdo de MS e os resultados da inoculação sobre as características de fermentação e desempenho animal não foram eficientes. CASTLE (1990) não observou benefícios consistentes para silagens com baixa MS (18\%) no tratamento com inoculantes bacterianos. Somente para valores acima de $25 \%$ é que houve melhoria nos padrões de fermentação em relação a silagens tratadas com ácido fórmico. A explicação seria que em baixos níveis de MS a atividade microbiana indesejável, tal como clostridios, é estimulada, enquanto que as bactérias láticas são inibidas devido a tensão superficial da água.

Outra questão é a relação que existe entre a qualidade de silagem produzida a nível de laboratório e resposta no desempenho animal. De acordo com LUTHER (1986), e ANDERSON et al. (1989), experimentos feitos em silos de laboratório têm indicado atividade homofermentativa eficiente com o uso de inoculantes. Contudo, esses resultados não têm 
sido comprovados em sistemas de produção em larga escala. Melhoras no valor alimentar têm sido obtidas para aditivos ácidos, notadamente ácido fórmico em relação a energia digestível, mas não para aditivos microbianos.

Existem poucos trabalhos relacionando melhoria no desempenho animal com silagem inoculada e quando ocorrem nem sempre essa melhoria é atribuida ao processo de fermentação. MERRY et al. (1993) revisando sobre qualidade da silagem e desempenho animal, encontraram diversos trabalhos sem relação entre os dois fatores, ou seja, alguns dados apresentam melhorias do desempenho animal e nenhuma melhoria da fermentação e vice-versa. Os autores sugerem que outros parâmetros para medição da qualidade de silagem deveriam ser utilizados, tal como digestibilidade. Nos estudos onde pequenos silos tem sido usados, relatos de melhoria na fermentação são mais frequentes, mas a avaliação de silagens através de animais geralmente não tem sido feita.

Procurou-se observar uma série de trabalhos onde os dados de desempenho animal (ganho de peso e produção de leite) foram relacionados com parâmetros fermentativos, digestibilidade e ingestão de MS. LUTHER (1986), estudando o efeito da inoculação microbiana sobre as características químicas e conservação de silagem de milho inoculada no desempenho de novilhos, não observou diferenças para $\mathrm{pH}$, concentrações de ácido lático ou recuperação de MS. Observou maior digestibilidade da MS, da proteína bruta e de retenção de $\mathrm{N}$. Porém não houve uma melhora no desempenho de animais. KENNEDY et al. (1989) e SHARP et al.(1994), observando o desempenho de animais alimentados com silagens inoculadas também não encontraram diferenças em relação à controle

GORDON (1989) avaliou a ação de inoculante de uma única estirpe ( $L$. plantarum) em silagem de gramineas fornecidas a vacas em 
lactação e não encontrou efeito das silagens inoculadas sobre as proporções de ácidos graxos voláteis no rúmen. WITTENBERG et al. (1983) estudando o efeito de aditivos bacterianos sobre a preservação de silagem de milho, verificaram que o mesmo não influenciou sobre as perdas de MS na fermentação. Estudos de crescimento e digestibilidade "in vivo" não apresentaram respostas para silagem de milho inoculada. A silagem controle usada neste estudo foi de boa qualidade e os ganhos adicionais pelo uso do inoculante foram mímimos.

De acordo com KUNG JR et al. (1993) a inoculação microbiana tem melhorado a fermentação de silagens de gramíneas e leguminosas, mas parece ter efeito mínimo sobre a fermentação de silagem de milho. Além disso, mudanças no processo fermentativo nem sempre são relacionadas com melhorias no desempenho animal. Eles estudaram o efeito de diferentes inoculantes microbianos, comercialmente disponiveis, sobre o valor nutritivo de silagem de milho para vacas em lactação. O tratamento com o inoculante Ecosyl (ICI biological Products) apresentou maior produção de ácido lático, mas também maior produção de ácido acético, sem mostrar efeito no desempenho de animais. O produto 1174 da Pioneer Hybrid International Inc. não teve efeito sobre a composição final da silagem e sobre o desempenho de animais. No entanto, ambos, aumentaram a produção de gordura no leite e a ingestão de MS.

Queda rápida do $\mathrm{pH}$ tem sido considerado um dos principais fatores para se produzir silagem de boa qualidade. ROOKE et al. (1988) encontraram menor $\mathrm{pH}$ para silagens inoculadas do que para silagens controles. Muitos processos indesejáveis que afetam diretamente a qualidade da silagem são dependentes de altos níveis de pH. HERON et al. (1986) afimam que o nível de proteólise na silagem está estritamente relacionado com a taxa de declínio do $\mathrm{pH}$, e isto parece ser mediado pela 
atividade da protease da planta a qual diminui com o decréscimo do $\mathrm{pH}$. Silagens inoculadas apresentam teoricamente $\mathrm{pH}$ mais baixo, menor atividade de microorganismos indesejáveis (clostrídios), maior grau de conservação e consequentemente maior desempenho animal.

Em revisões realizadas por McDONALD et al. (1991), diversos trabalhos mostraram aumento na ingestão da MS da silagem sem nenhuma relação com melhorias na fermentação. Rápidos declínios do pH podem inibir a atividade da enterobactéria, reduzindo a produção de endotoxinas, o que poderia aumentar a ingestão da silagem. 


\section{MATERIAL E MÉTODOS}

O trabalho foi desenvolvido no departamento de Zootecnia Setor de Ruminantes, da Escola Superior de Agricultura "Luiz de Quieroz" da Universidade de São Paulo (ESALQ-USP) no município de PiracicabaSP situado a $22^{\circ} 45^{\prime}$ de latitude sul, e $47^{\circ} 38^{\prime}$ de longitude oeste e a uma altitude de $537 \mathrm{~m}$.

A avaliação do efeito do inóculo comercial "1174" da. Pioneer Sementes Ltda foi realizada em duas fases distintas: silagem com alta matéria seca (MS) - Experimento I, e silagens com teor alto e baixo de MS - Experimento II.

Em ambos os experimentos, as silagens foram produzidas com milho, cultivar 3210 da Pioneer Sementes Ltda, plantado no início da estação chuvosa (outubro de 1992 para o experimento I e outubro de 1993 para o experimento II). Após 90 dias da semeadura foram amostradas plantas inteiras para determinação de MS. 


\subsection{Experimento I - Silagem com alta matéria seca}

A ensilagem foi efetuada em dois silos de concreto tipo poço com capacidade para 12 toneladas, os quais foram enchidos simultâneamente, alternando-se as carretas que vinham do campo com material para ser ensilado num período de dois dias.

O inóculo comercial 1174 contendo Lactobacilus plantarum e Streptococus faecium foi preparado diariamente numa suspensão aquosa $\left(9,0 * 10^{10}\right.$ unidades formadoras de colonias (UFC)/grama do produto) e aplicado uniformemente com pulverizador costal-manual com bico para baixa pressão a uma dosagem de $1 \mathrm{ppm}$.

As carretas advindas do área de colheita recebiam duas apliacações, uma na parte superior da mesma, e outra após o descarregamento, antes da distribuição e compactação. A forragem foi ensilada com MS de 41,4\%.

\subsubsection{Avaliação de aditivo bacteriano para silagem sobre o desempenho de bovinos.}

A condução do ensaio constou de 15 dias de adaptação e 36 de período experimental. Foram usados 16 bovinos machos inteiros da raça Nelore com peso inicial médio de $350 \mathrm{Kg}$ PV aos 18 meses de idade, distribuídos individualmente em baias com piso de concreto, cocho coberto e área de $28 \mathrm{~m}^{2}$ cada. 
As dietas experimentais utilizadas foram silagens com alta MS, inoculada e não inoculada fornecidas ad libitum, sendo que o nível de proteína (12\%) foi ajustado na MS, com farelo de algodão e uréia, segundo o sistema de modelagem da Universidade de Cornell (Tabela 3). O fornecimento dessas dietas ocorria diariamente, no final da tarde, quando eram amostradas as sobras, após coleta e pesagem. Os alimentos eram coletados para amostra duas vezes por semana. Todas as amostras coletadas eram encaminhadas ao Laboratório de Bromatologia da ESALQUSP e armazenados em frezeers. No final do ensaio todas as amostras de alimentos e sobras foram secadas em estufa de circulação forçada a $65^{\circ} \mathrm{C}$ por $48 \mathrm{~h}$ e posteroirmente seguiam em análises bromatológicas.

Tabela 3. Proporção dos ingredientes nas dietas experimentais.

\begin{tabular}{ll}
\hline \multicolumn{1}{c}{ COMPONENTES } & $\% \mathrm{MS}$ \\
\hline SILAGEM DE MILHO & 89,20 \\
FARELO DE ALGODÃO(38\% PB) & 9,25 \\
URÉIA & 0,78 \\
MINERAL & 0,77 \\
\hline
\end{tabular}

Obs.: Dieta ajustada para $12 \%$ de PB na MS

Foram feitos ajustes 2 vezes/semana na quantidade da dieta fornecida, com base na sua MS e na quantidade e MS das sobras.

Os animais foram pesados quinzenalmente após jejum de 18 horas.

Os parâmetros avaliados foram os seguintes: consumo de $\mathrm{MS}(\mathrm{Kg}$ MS/animal/dia), consumo de MS em \% do peso vivo, consumo de MS em $\mathrm{g} / \mathrm{Kg}$ de $\mathrm{PV}^{0,75}$, ganho de peso vivo diário (Kg/animal/dia) e conversão alimentar (Kg MS/Kg ganho de peso). 
As análises estatísticas dos efeitos das dietas sobre os diferentes parâmetros avaliados foram efetuadas utilizando-se 0 delineamento inteiramente casualizado, com 2 tratamentos e 8 repetições, onde cada animal constituiu uma parcela. O programa utilizado foi o SAS através do PROC-GLM (SAS, 1988).

\subsubsection{Avaliação da aditivação do inoculante bacteriano através da digestibilidade "in vivo" em ovinos.}

O experimento foi desenvolvido em quatro períodos de coleta, tendo cada um a duração de 7 dias intercalados com 15 dias de adaptação.

Foram usados 6 carneiros da raça Corriedale com média de $30 \mathrm{Kg}$ de PV, distribuidos individualmente em gaiolas metabólicas, recebendo as mesmas dietas experimentais utilizadas no ensaio com bovinos, porém com 2 níveis de fornecimento: alto e baixo $\left(65\right.$ e $45 \mathrm{~g} / \mathrm{Kg}$ de $\mathrm{PV}^{0,75}$ respectivamente) em período alternados, ou seja, nos períodos 1 e 3 , à vontade, e 2 e 4 , restrito, de acordo com esquema a seguir:

\begin{tabular}{llll}
\hline Período 1 & Período 2 & Período 3 & Perído 4 \\
\hline $1,2,3-$ IV & $1,2,3-$ IR & $1,2,3-$ NIV & $1,2,3-$ NIR \\
$4,5,6-$ NIV & $4,5,6-$ NIR & $4,5,6-$ IV & $4,5,6-$ IR \\
\hline
\end{tabular}

sendo: $1,2,3,4,5,6$ - número dos carneiros

IR-inoculado restrito; IV-inoculado à vontade; NIR-não inoculado restrito: NIV- não inoculado à vontade. 
As dietas eram fornecidas duas vezes ao dia a cada 12 horas, sendo metade pela manhã e metade no final da tarde. No final da tarde também eram realizadas as coletas de alimetos, sobras e fezes.

Durante os 7 dias de coleta eram amostradas diariamente $10 \%$ das fezes, sobras e alimentos e encaminhados ao Laboratório de Bromatologia da ESALQ-USP onde eram armazenados em freezer para posterior secagem em estufa de circulação forçada a $65^{\circ} \mathrm{C}$ por $48 \mathrm{~h}$. As coletas de alimentos começavam sempre dois dias antes do início da coleta de fezes.

As pesagens dos animais ocorreram no início e final de cada período de coleta.

Os parâmetros avaliados foram: digestibilidade da MS e dos componentes da MS: nitrogênio (N), fibra em detergente neutro (FDN), fibra em detergente ácido (FDA), lignina, extrato etéreo, além do balanço de nitrogênio. Os dados obtidos foram analisados de acordo com o delienamento inteiramente casualisado com 4 tratamentos e 6 repetições, sendo cada carneiro uma parcela. O programa utilizado foi o SAS através do proc GLM (SAS, 1988).

\subsubsection{Avaliação da aditivação do inoculante bacteriano quanto à recuperação da MS da silagem.}

No interior de 2 silos tipo poço, um com silagem inoculada e um com silagem não inoculada, foram colocados 8 sacos plásticos perfurados ( 4 sacos por silo) previamente pesados com $10 \mathrm{Kg}$ de silagem em média, contendo as respectivas forragens inoculada e não inoculada, dispostos em 
4 profundidades, para avaliação das alterações na composição da silagem e recuperação da MS. As profundidades foram 1,4, 1,9, 2,5 e 3,3m.

Os sacos foram recuperados ao longo do período experimental do confinamento e digestibilidade com carneiros através da retirada diária da silagem.

Foram avaliados os seguintes parâmetros no conteúdo dos sacos: nitrogênio total, nitrogênio amoniacal $\left(\mathrm{N}-\mathrm{NH}_{3}\right), \mathrm{pH}$ e recuperação da $\mathrm{MS}$ expressa em \% em relação à quantidade inicial contida no saco.

Os dados foram analisados segundo o delineamento inteiramente casualisado com 2 tratamentos (2 tipos de silagens em 4 profundidades).

\subsubsection{Avaliação da aditivação do inoculante bacteriano quanto ao perfil da fermentação de silagem de milho. .}

No momento da colheita da forragem foram confeccionados 24 mini-silos com $20 \mathrm{Kg}$ em média, distribuídos igualmente em dois tratamentos (com e sem inoculação) e 3 repetições.

Os parâmetros observados foram temperatura $\left({ }^{\circ} \mathrm{C}\right)$ e $\mathrm{pH}$ durante o processo fermentativo (0,24, 48, 96 e 192 horas pós-ensilagem). No tempo zero as avaliações foram feitas em forragem fresca e, em cada tempo após a ensilagem, eram abertos três mini-silos por tratamento. Dois outros mini-silos, contendo silagem inoculada e não inoculada, tinham termômetros de bulbo de mercúrio inseridos no centro da massa ensilada. 
O delineamento estatístico utilizado foi inteiramente casualizado, com 10 tratamentos ( 2 tipos de silagem e 5 tempos de fermentações) e 3 repetições.

\subsection{Experimento II - Silagens com diferentes teores de matéria seca}

Os ensaios desenvolvidos nesta fase tiveram parte da forragem colhida aproximadamente aos 90 dias após semeadura objetivando, conseguir teores mais baixos de MS (28 a 33\%), e o restante colhido por volta de 110 dias, com teores mais elevados ( 35 a $40 \%$ ).

As silagens foram armazenadas em 12 silos tipo poço, tendo cada um a capacidade para 12 toneladas, onde foram distribuidos 4 tipos de silagens (tratamentos): inoculada com alta MS, não inoculada com alta MS, inoculada com baixa MS, não inoculada com baixa MS, com 3 repetições. O processo de enchimento deu-se de forma alternada de modo que dois silos com o mesmo teor de MS, com e sem inoculação eram enchidos simultaneamente.

Os critérios utilizados para a produção da silagem inoculada e não inoculada foram os mesmos observados para o experimento $\mathrm{I}$. 


\subsubsection{Avaliação da aditivação do inoculante bacteriano sobre a digestibilidade "in vivo" em bovinos.}

Nesse experimento foram utilizados 8 bovinos machos castrados da raça Nelore com $350 \mathrm{Kg}$ de $\mathrm{PV}$. Inicialmente os animais foram submetidos a 30 dias de treinamento para adaptação às condições de completa contenção nas gaiolas metabólicas, procurando-se evitar "stress". As gaiolas mediam $1,06 \mathrm{~m}$ de largura, e o comprimento era ajustável de acordo com o tamanho do animal.

A alimentação era fornecida a cada 12 horas, metade pela manhã e metade no final da tarde, em cochos individuais.

Os 8 animais foram sorteados equitativamente nos 4 tipos de silagens, com 8 períodos de coletas de 7 dias, sendo 4 períodos com fornecimento de $60 \mathrm{~g} / \mathrm{Kg} \mathrm{PV}^{0,75}$ e 4 períodos de $80 \mathrm{~g} / \mathrm{Kg}$ de $\mathrm{PV}^{0,75}$, conforme esquema abaixo.

\begin{tabular}{|c|c|c|c|c|}
\hline \multirow[t]{2}{*}{ Animais } & \multicolumn{4}{|c|}{ Períodos } \\
\hline & I e II & III e IV & $\mathrm{V}$ e VI & VII e VIII \\
\hline 1 e 2 & $\mathrm{AI}$ & AÑI & BI & $\mathrm{BNI}$ \\
\hline 3 e 4 & AÑI & $\mathrm{AI}$ & BÑI & BI \\
\hline 5 e 6 & BI & BÑI & AI & AÑI \\
\hline 7 e 8 & BÑI & BI & AÑI & AI \\
\hline
\end{tabular}

I, III, V e VII períodos com fornecimento de $80 \mathrm{~g} / \mathrm{Kg} \mathrm{PV}^{0,75}$ e II, IV, VI e VIII períodos com fornecimento de $60 \mathrm{~g} / \mathrm{Kg} \mathrm{PV}^{0,75}$.

1 a 8 - número dos animais;

AI-alta MS inoculado; AÑI-alta MS não inoculado; BI-baixa MS inoculado; BÑI-baixa MS não inoculado. 
Após cada período de fornecimento mais alto seguia-se uma adaptação de 7 dias com fornecimento mais baixo e posterior coleta de 7 dias, no qual os animais recebiam o mesmo tipo de tratamento. No final deste período de coleta, os animais passavam a receber outro tratamento, sendo submetidos a novo intervalo de 15 dias de adaptação.

Nos períodos de coleta foram amostrados $10 \%$ do total diário das fezes e alimentos, e posteriormente encaminhados ao Laboratório de Bromatologia da ESALQ-USP. As pesagens dos animais ocorriam no início e final de cada período.

Os parâmetros avaliados foram: digestibilidade da MS e dos componentes da MS (FDN, FDA, lignina, nitrogênio, nitrogênio insolúvel detergente neutro (NIDN), nitrogênio insolúvel em detergente ácido (NIDA), extrato etéreo).

O delineamento estatístico empregado na análise das variáveis foi inteiramente casualizado, com esquema fatorial $4 \times 2$ (MS alta com e sem inoculação, MS baixa com e sem inoculação, e fornecimentos de $60 \mathrm{~g} / \mathrm{Kg}$ $\mathrm{PV}^{0.75}$ e $80 \mathrm{~g} / \mathrm{Kg} \mathrm{PV}^{0.75}$ ) e 2 repetições.

\subsubsection{Avaliação da aditivação do inoculante bacteriano sobre a degradabilidade "in situ" de silagens inoculadas.}

Foram utilizados 3 bovinos machos castrados da raça Nelore, fistulados, com média de $600 \mathrm{Kg}$ de peso vivo, colocados em gaiolas individuais onde receberam alimentação e água individualmente. 
Antes do início dos períodos experimentais os animais foram submetidos a um período extra de treinamento de 30 dias visando uma melhor adaptação às gaiolas, para evitar "stress".

Os 3 animais foram submetidos aos 4 tratamentos (silagem inoculada com alta MS, silagem não inoculada com alta MS, silagem inoculada com baixa MS e silagem não inoculada com baixa MS) durante 4 períodos, sendo que em cada período uma das silagens não foi avaliada. Este procedimento foi adotado porque um $4^{\circ}$ animal não foi adaptado às instalações. Cada animal recebeu por dia $60 \mathrm{~g} / \mathrm{Kg}$ de $\mathrm{PV}^{0,75}$.

As coletas constaram de 4 períodos. Cada período com 15 dias de adaptação e 4 de coleta. Os tempos de incubação no rúmen foram de 3,6 , $12,24,36,48$ e 72 horas para silagem, e de 2, 4, 6, 8, 12, 24 e 48 horas para farelo de algodão. O objetivo da incubação do farelo de algodão foi verificar se havia efeito do inoculante sobre a degradação do concentrado da dieta.

A silagem de milho foi moída em peneira de $5 \mathrm{~mm}$ e o farelo de algodão em peneira de $2 \mathrm{~mm}$ e colocados em sacos de $7 \times 14 \mathrm{~cm}$, confeccionados em naílon ( $100 \%$ poliamida, resistente a alta temperatura, não resinado) com porosidade de 50 micra, na quantidade de $5,5 \mathrm{~g}$ de amostra/saco.

Os sacos de náilon contendo amostras foram previamente lavados em água a $39^{\circ} \mathrm{C}$ por 15 minutos para remoção do material solúvel nas porções pré-ruminais e posteriormente secados em estufa de circulação forçada a $55^{\circ} \mathrm{C}$ por 72 horas.

Nos alimentos foram determinados MS, extrato etéreo, cinzas e $\mathrm{N}$ total, seguindo os métodos da A.O.A.C. (1975); FDN, FDA, NIDN, segundo VAN SOEST \& ROBERTSON (1985); carboidratos solúveis 
(CHO-sol) de acordo com JOHNSON et al. (1966) e amido pela metologia apresentada por PEREIRA \& ROSSI (1995); nitrogênio solúvel e nitrogênio protéico, segundo KRISHNAMOORTHY et al. (1982).

No resíduo da degradação "in situ" foram determinados MS, N total, FDN e NIDN, para posterior obtenção das respectivas taxas de degradação.

A determinação da degradabilidade potencial (DP) das diferentes frações analisadas foi calculada segundo modelo proposto por MEHREZ \& ORSKOV (1977).

$$
D P=A+B\left(1-e^{-c t}\right)
$$

sendo:

DP- potencial de degradação da fração;

A- componente solúvel (\%), obtida através do processo de lavagem dos sacos;

B- componente potencialmente degradável (\%), obtido por 100 $(A+C)$

C- componente indegradável obtido no final do processo de degradação (\%);

c- taxa de desaparecimento do componente B por hora obtida através da regressão do logarítmo natural do resíduo potencialmente degradável.

A degradabilidade efetiva (DE) foi calculada de acordo com o modelo sugerido por ORSKOV \& McDONALD (1979): 


$$
\mathrm{DE}=\mathrm{A}+[(\mathrm{B} \times \mathrm{c}) /(\mathrm{c}+\mathrm{K})]
$$

sendo:

K- taxa de passagem da fase sólida da dieta

O delineamento experimental utilizado foi de blocos incompletos balanceados com 4 tratamentos (tipos de silagens), 3 parcelas (animais) e 4 repetições (períodos).

\subsubsection{Avaliação da taxa de passagem de dietas à base de silagens tratadas com inóculos bacterianos}

No decorrer do ensaio de degradação os mesmos animais foram utilizados para determinações das taxas de passagem da fase sólida, utilizando-se da técnica do cromo mordente (UDÉN et al., 1980).

No rúmen dos animais foi introduzido, via cânula, em torno de $100 \mathrm{~g}$ de fibra de silagem insolúvel em detergente neutro marcada com óxido de cromo. Após $0,12,16,20,24,28,32,36,42,48,54,60,72$ e 84 horas da introdução, efetuou-se coleta de fezes do reto dos animais.

A recuperação do cromo deu-se por intermédio de uma digestão ácida e posterior leitura em espectofotômetro de absorção atômica.

A determinação da taxa de passagem foi feita através da regressão do logarítmo natural a partir do tempo em que se observou a maior concentração de cromo nas fezes.

A análise estatística dos dados foi realizada de modo semelhante ao experimento de degradabilidade "in situ". 


\section{4-RESULTADOS E DISCUSSÃO}

\subsection{EXPERIMENTO I - Silagem com alta matéria seca}

\subsubsection{Avaliação do aditivo bacteriano para silagem no desempenho de bovino}

$\mathrm{Na}$ Tabela 4 são apresentados os valores médios de composição bromatológica das duas dietas oferecidas aos animais em confinamento. Não se identificaram diferenças entre a silagens inoculada e sem inoculação, quanto ao teor de MS, porcentagens de nitrogênio, extrato etéreo e fibra em detergente neutro(FDN), fibra em detergente ácido (FDA) e lignina.

Tabela 4. Composição média das dietas experimentais à base de silagem de milho, com e sem inoculante, oferecidas a bovinos em confinamento.

\begin{tabular}{lcc}
\hline Parâmetros $(\%)^{*}$ & Inoculada & Não inoculada \\
\hline Matéria seca & 50,16 & 49,48 \\
Nitrogênio & 1,91 & 1,93 \\
Extrato etéreo & 2,21 & 2,29 \\
Fibra em detergente neutro & 49,13 & 50,77 \\
Fibra em detergente ácido & 30,42 & 30,03 \\
Lignina & 3,66 & 3,91 \\
\hline (*) Porcentagem em
\end{tabular}

Os dados de desempenho de bovinos em confinamento são mostrados na Tabela 5. As médias das dietas estudadas não apresentaram 
diferenças significativas $(P>0,05)$ com relação aos parâmetros ingestão de MS, consumo de MS em \% do peso vivo, consumo de $\mathrm{MS}$ em $\mathrm{g} / \mathrm{Kg} \mathrm{PV}^{0,75}$, ganho de peso vivo diário e conversão alimentar. Os altos níveis de silagem de milho na dieta, não provocaram dimuição dos ganhos médios diários quando comparados com outros trabalhos. Poderia-se esperar menores ganhos devido a uma possível diminuição do equivalente energético da dieta, o que provocaria um menor ganho dos animais. Estes dados são concordantes com resultados obtidos por LUTHER (1986), que não encontrou repostas significativas no desempenho de animais tratados com silagem de alta matéria seca (39\%) aditivada com microorganismos. $O$ referido autor usou também altas quantidades de silagem de milho na dieta $(90 \%)$ e obteve ingestão de matéria seca (IMS), ganho de peso vivo e conversão alimentar de 7,82 vs 7,$63 ;, 1,19$ vs 1,$17 ; 6,59$ vs 6,53 , respectivamente para silagens tratadas e não tratadas. KENNEDY et al.(1989), avaliando o efeito de um inoculante bacteriano no desempenho de animais em confinamento também não encontraram respostas significativas tanto para ingestão de MS como para desempenho animal.

Tabela 5. Efeito da aditivação do inoculante bacteriano em silagem de milho sobre o desempenho de bovinos confinados

\begin{tabular}{lccc}
\hline \multirow{2}{*}{ Parâmetros $\left(^{*}\right)$} & \multicolumn{2}{c}{ Silagens de milho } & CV (\%) \\
\cline { 2 - 3 } & inoculada & não inoculada & \\
\hline IMS (kg MS/animal/dia) & 7,82 & 8,22 & 9,84 \\
CPV (\%) & 2,34 & 2,42 & 7,78 \\
CPM (g/Kg PV & 100,06 & 103,82 & 7,10 \\
GPV (Kg/animal/dia) & 1,23 & 1,26 & 19,39 \\
CA (Kg MS/kg de ganho) & 6,35 & 6,52 & 18,22 \\
\hline
\end{tabular}

(*) IMS: Ingestão de matéria seca); CPV: consumo de matéria seca; CPM: consumo de matéria seca em peso metabólico; GPV: ganho de peso vivo diário;CA: conversão alimentar.

Estudos feitos por WITTENBERG et al. (1983) com silagem de milho inoculada e não inoculada não mostraram efeitos no desempenho 
animal de novilhos. Os autores sugerem que a inoculação bacteriana não melhora o valor alimentar final da silagem de milho quando o processo de colheita e as técnicas de ensilagem conduzem a uma boa fementação do material colhido.

No presente estudo, observou-se que tanto a silagem controle como a inoculada tiveram igual valor alimentar. Isto sugere que quando se tem substrato adequado, tais como fontes de carboidratos prontamente disponiveis e boas técnicas de ensilagem, a microflora normal é suficiente para uma boa fermentação.

Com o propósito de avaliar a eficiência de inoculantes bacterianos para a produção de silagem de gramíneas, SHARP et al. (1994), encontraram que as silagens tratadas apresentaram maior produção de lactato, mas as melhorias do processo fermentativo não foram refletidas em maior ganho de peso para os animais.

Silagens bem preservadas resultantes de mais rápido declínio do pH devido à dominância de bactérias láticas, teriam uma menor atividade de enterobactérias o que reduziria a produção de endotoxinas e aumentaria a ingestão da silagem. No entanto, como visto na Tabela 5 não houve diferença para ingestão de MS entre as silagens estudadas.

\subsubsection{Avaliação da aditivação do inoculante bacteriano na digestibilidade "in vivo" em ovinos}

$\mathrm{Na}$ Tabela 6 são apresentados os resultados de digestibilidade aparente dos parâmentros MS (DMS), nitrogênio (DNIT), extrato etéreo (DEE), FDN (DFDN), FDA (DFDA) e lignina (DLIG) de silagem de milho inoculada com aditivos bacterianos e não inoculada. Os resultados mostraram diferenças não significativas entre os tratamentos para DMS, DNIT, DEE e DLIG tanto para o nível alto como para o baixo $(\mathrm{P}>0,10)$. 
Tabela 6. Digestibilidade aparente de dietas a base de silagem de milho inoculada e sem inoculação, com baixo e alto fornecimentos, oferecidas a ovinos

\begin{tabular}{|c|c|c|c|c|}
\hline \multirow{2}{*}{$\begin{array}{c}\text { Parâmetros } 1 \\
(\%)\end{array}$} & \multirow[t]{2}{*}{ Tipo de fornecimento 2} & \multicolumn{2}{|c|}{ Silagens } & \multirow[t]{2}{*}{$\mathrm{CV}(\%)$} \\
\hline & & inoculada & não inoculada & \\
\hline \multirow[t]{2}{*}{ DMS } & baixo & 69,0 & 69,7 & 2,23 \\
\hline & alto & 67,2 & 65,6 & \\
\hline \multirow[t]{2}{*}{ DNIT } & baixo & 79,9 & 80,8 & 2,13 \\
\hline & alto & 79,6 & 80,9 & \\
\hline \multirow[t]{2}{*}{ DEE } & baixo & 89,8 & 89,1 & 0,98 \\
\hline & alto & 88,1 & 88,8 & \\
\hline \multirow[t]{2}{*}{ DFDN } & baixo & 54,1 & 56,8 & 4,74 \\
\hline & alto & $51,5 \mathrm{a}$ & $44,1 \quad b, B$ & \\
\hline \multirow[t]{2}{*}{ DFDA } & baixo & 54,9 a & $47,0 \mathrm{~b}, \mathrm{~A}$ & 11,61 \\
\hline & alto & 53,5 a & $37,6 \mathrm{~b}, \mathrm{~B}$ & \\
\hline \multirow[t]{2}{*}{ DLIG } & baixo & 41,1 & 43,3 & 16,42 \\
\hline & alto & 44,6 & 37,1 & \\
\hline
\end{tabular}

${ }^{1}$ DMS: digestibilidade da matéria seca; DNIT: digestibilidade do nitrogênio, DEE: digestibilidade do extrato etéreo; DFDN: digestibilidade da fibra em detergente neutro; DFDA: digestibilidade da fibra em detergente ácido; $e$ DLIG: digestibilidade de lignina;

${ }^{2}$ Baixo: $45 \mathrm{~g} / \mathrm{Kg} \mathrm{PV}^{0,75}$; alto: $65 \mathrm{~g} / \mathrm{Kg} \mathrm{PV}^{0,75}$ );

a,b-médias na mesma linha seguidas de letras distintas, diferem significativamente entre si pelo teste de Tukey $(\mathrm{P}<0,10)$;

$A, B$-médias na mesma coluna seguidas de letras distintas, diferem significativamente entre si pelo teste de Tukey $(\mathrm{P}<0,10)$.

A interação tratamento e nível de ingestão foi significativa para DFDN e DFDA $(P<0,10)$. Para DFDN, no fornecimento mais alto, houve uma maior digestibilidade para silagem inoculada do que para silagem não inoculada $(\mathrm{P}<0,10)$. Para DFDA houve maior digestibilidade para silagem inoculada nos dois niveis de fornecimento $(P<0,10)$. Na silagem inoculada o nível de ingestão não afetou significativamente a DFDN e a DFDA $(P>0,10)$, enquanto na silagem não inoculada o efeito do nível de ingestão 
na DFDN e DFDA foi significativo e maior para o fornecimento mais baixo $(\mathrm{P}<0,10)$.

Os resultados de maior digestibilidade da fibra (DFDN e DFDA) em silagem inoculada poderiam ser explicados pelas constatações de JONES et al. (1992). Revisões desses autores sobre ensilagem de gramíneas demonstrou que a hemicelulose pode ser degradada tanto por enzimas da planta como por hidrólise ácida. Esta degradação durante a ensilagem tem resultado na redução da fibra em detergente neutro (FDN) quando comparado com o material original. Os resíduos de arabana são ácidos lábeis e substituições reduzidas de arabanas por xilanas tem aumentado a degradação ruminal de xilanas. Trabalhos desses autores com alfafa encontraram uma diminuição da arabana da parede celular e um aumento dos teores de xilana como resultado da hidrólise ácida do processo de ensilagem. Assim a ocorrência de mais hidrólise ácida em silagens inoculadas, conduz à maior conversão de arabana em xilana e, consequentemente, maior digestibilidade da silagem.

O efeito da inoculação na digestibilidade ou na composição da parede celular pode ser devido a menor $\mathrm{pH}, \mathrm{o}$ que aumentaria a quantidade de hidrólises ácidas sobre os constituintes da parede celular. Mas segundo JONES et al. (1992) as hidrólises ácidas dos açúcares da parede celular não podem ser diferenciadas entre silagens inoculadas e não inoculadas com apenas um diferença de 0,3 unidades do $\mathrm{pH}$. Para os referidos autores resposta limitada a altas taxas de inoculação nas características finais de um material ensilado pode ser devido a quantidade de substrato insuficiente para o processo de fermentação.

Por outro lado ROOKE et al. (1988), estudando a composição química e o valor nutritivo de gramíneas com e sem a adição de inoculante encontraram diminuição da digestibilidade da fibra em detergente ácido modificado quando oferecido a carneiros. Foram observados também rápida queda do $\mathrm{pH}$, menor produção de amônia, maior produção de ácido 
lático e menor produção de acético, em silagens inoculadas. Os autores sugerem que a degradação de porções mais facilmente digestíveis da parede celular pode ter ocorrido no silo. Decréscimos no conteúdo da parede celular do material ensilado tem sido observado como resultado de hidrólises ácidas, ação de microorganismos ou atividade residual de enzimas da planta durante o período de estocagem.

\subsubsection{Efeito da aditivação do inoculante bacteriano na recuperação da matéria seca da silagem de milho.}

Na Tabela 7 são apresentados dados médios de recuperação da matéria seca em silagens de milho inoculada e sem inoculação, em diferentes profundidades dos silos poço. Os resultados não apresentaram diferenças significativas entre as silagens. Os valores médios de recuperação acima de $90 \%$ são representativos de silagens com alta MS. Os tratamentos não diferiram significativamente entre diferentes profundidades. Também não foram verificadas diferenças entre tratamentos.

Tabela 7. Efeito da aditivação do inoculante bacteriano na recuperação da matéria seca (\%) de silagem de milho em silos tipo poço.

\begin{tabular}{ccc}
\hline Profundidades $(\mathrm{m})$ & \multicolumn{2}{c}{ Silagens de milho } \\
& inoculada & não inoculada \\
\hline 3,3 & 99,3 & 98,3 \\
2,5 & 94,2 & 90,1 \\
1,9 & 88,1 & 88,2 \\
& 91,2 & 95,3 \\
\hline Média & 95,9 & 93,0 \\
\hline CV $(\%)=5,61$ & &
\end{tabular}

Segundo McDONALD et al. (1991) o conteúdo de MS, tipo de silo, nível de conservação no silo e pré-tratamentos são fatores que influenciam a perda por efluente, sendo que o conteúdo de MS é o principal deles. Em material ensilado com MS entre 25 e $35 \%$ muito 
pouco efluente pode ser produzido, exceto em silos torre onde a pressão pode ser alta.

Resultados de LUTHER (1986) sobre recuperação da MS foram semelhantes aos encontrados neste estudo, inclusive sem diferenças entre tratamentos $(88,3 ; 88,1 \%$ para silagens controle e inoculada, respectivamente). E WITTENBERG et al. (1983), trabalhando com silagem de milho com $32,3 \% \mathrm{MS}$, encontraram perdas na preservação de $9,2 \%$ e $8,6 \%$ para silagens controle e inoculada, respectivamente, que também não diferiram entre si.

\subsubsection{Avaliação da aditivação do inoculante bacteriano quanto ao perfil de fermentação de silagem de milho}

O principal objetivo do experimento foi avaliar o valor nutritivo da silagem com aditivo bacteriano. Assim foi importante estabelecer se microoganismos deste aditivo tinham dominado o processo de fermentação. Na ausência de dados microbiológicos, as mudanças na composição química da silagem com o tempo foram monitoradas nos silos tipo poço e em silos de laboratório (Tabelas 8 e 9).

Os parâmetros obtidos nos silos (Tabela 8) não mostraram diferenças significativas entre silagens inoculada e não inoculada $(\mathrm{P}>0,05)$. A composição das duas silagens demonstrou alta MS e baixa proteina bruta (N-TOTAL x 6,25). Os valores de proteina e nitrogênio amoniacal foram semelhantes nos dois tipos de silagem e próximos aos da forragem fresca. Os valores de nitrogênio amoniacal da forragem fresca pode ser considerado alto, indicando que a mesma pode ter sofrido proteólise no decorrer do tempo de estocagem, entre a coleta da forragem no campo e a época de análise no laboratório. Os valores de $\mathrm{pH}$ abaixo de 4 demonstram que as duas silagens foram bem conservadas. 
Tabela 8. Composição bromatológica de silagens de milho inoculadas e não inoculadas, em decorrência do processo fermentativo em silos tipo poço, e na forragem original

\begin{tabular}{|c|c|c|c|c|}
\hline Parâmetros & Coletas & Silagen & de milho & CV (\%) \\
\hline & & inoculada & ñ inoculada & \\
\hline MS (\%) & inicial & 42,0 & 40,8 & 7,86 \\
\hline & dentro & 44,8 & 43,7 & \\
\hline & fora & 41,7 & 40,2 & \\
\hline N-TOTAL $(\%)^{2}$ & inicial & 1,08 & 1,14 & 7,14 \\
\hline & dentro & 1,02 & 1,03 & \\
\hline & fora & 1,06 & 1,04 & \\
\hline N-AMONIACAL(\%) ${ }^{2}$ & inicial & 0,12 & 0,11 & 29,34 \\
\hline & dentro & 0,12 & 0,12 & \\
\hline & fora & 0,13 & 0,16 & \\
\hline $\mathrm{pH}$ & inicial & 5,40 & 5,42 & 10,36 \\
\hline & dentro & 3,72 & 3,67 & \\
\hline & fora & 3,75 & 3,81 & \\
\hline
\end{tabular}

Os dados relacionados aos parâmetros fermentativos de silos de laboratório indicaram uma rápida queda do $\mathrm{pH}$ para ambas as silagens (Tabela 9). Isto demonstra que tanto nas silagens inoculadas como nas não inoculadas, estirpes de bactérias láticas rapidamente dominaram a fermentação. Este resultados estão concordantes com WOOLFORD \& SAWCZYC (1984b) que não observaram influência notável sobre o desenvolvimento microbiano, sobre a taxa de acidificação e sobre a promoção da fermentação homolática com nenhuma das culturas ou misturas de culturas aplicadas em silagens de trevo branco e azevém.

Reduções nos níveis de $\mathrm{pH}$ e nitrogênio amoniacal foram observadas em outros trabalhos desenvolvidos com diferentes silagens inoculadas. KUNG et al. (1990), observaram que silagem de cevada e ervilhaca inoculadas, reduziram o $\mathrm{pH}$, o nível de acetato e o nitrogênio 
amoniacal e aumentou as concentrações de lactato, caracterizando um melhor processo fermentativo da silagem. Os autores afirmam que os resultados de inoculação bacteriana de silagem podem melhorar a qualidade da mesma desde que exista substrato suficiente para o processo de fermentação.

Tabela 9. Resultados médios obtidos para a variação de $\mathrm{pH}$ e temperatura ao longo do tempo após ensilagem, nos silos de laboratório.

\begin{tabular}{|c|c|c|c|c|}
\hline \multirow[t]{2}{*}{ Parâmetros } & \multirow[t]{2}{*}{ Tempo (h) } & \multicolumn{2}{|c|}{ Silagem de milho } & \multirow[t]{2}{*}{$\mathrm{CV}(\%)$} \\
\hline & & inoculada & $\tilde{n}$ inoculada & \\
\hline \multirow[t]{5}{*}{$\mathrm{pH}$} & 0 & $5,42 \mathrm{c}$ & $5,41 \mathrm{c}$ & \multirow[t]{5}{*}{0,46} \\
\hline & 24 & $3,90 \mathrm{~d}$ & $3,92 \mathrm{~d}$ & \\
\hline & 48 & $3,82 \mathrm{~d}, \mathrm{e}$ & $3,77 \mathrm{~d}, \mathrm{e}$ & \\
\hline & 96 & $3,75 \mathrm{e}$ & 3,74 e & \\
\hline & 192 & $3,72 \mathrm{e}$ & 3,73 & \\
\hline \multirow[t]{5}{*}{ Temperatura $\left({ }^{\circ} \mathrm{C}\right)$} & 0 & $34 \mathrm{c}$ & $34 \mathrm{c}$ & \multirow[t]{5}{*}{1,08} \\
\hline & 24 & $30 \mathrm{~d}$ & $31 \mathrm{~d}$ & \\
\hline & 48 & $28 \mathrm{e}$ & $28 \mathrm{e}$ & \\
\hline & 96 & $28 \mathrm{e}$ & $28 \mathrm{e}$ & \\
\hline & 192 & $26 \mathrm{f}$ & $26 \mathrm{f}$ & \\
\hline
\end{tabular}

ANDERSON et al. (1989) também encontraram queda rápida do $\mathrm{pH}$, menor conteúdo de amonia e acetato e maior digestibilidade dos nutrientes de azevém ensilado com inoculante bacteriano. Já ROOKE et al. (1988) obtiveram dados semelhantes aos anteriores, em silagens de gramineas inoculadas: menor $\mathrm{pH}$, maior quantidade de ácido lático e menor quantidade de ácido acético e $\mathrm{N}-\mathrm{NH}_{3}$ como resultado da dominância da fermentação por L. plantarum. 


\subsection{Experimento II - Silagens com diferentes níveis de matéria seca}

A composição bromatológica dos diferentes tipos de silagens com alta e baixa matéria seca, com e sem inoculante, e do farelo de algodão são apresentados na Tabela 10 .

Tabela 10. Composição bromatológica de silagens de milho inoculada e não inoculada, com alta e baixa matéria seca, e farelo de algodão.

\begin{tabular}{|c|c|c|c|c|c|c|}
\hline \multirow[t]{2}{*}{ Fração } & \multirow[t]{2}{*}{ Unidade } & \multicolumn{2}{|c|}{ Alta matéria seca } & \multicolumn{2}{|c|}{ Baixa matéria seca } & \multirow{2}{*}{$\begin{array}{l}\text { Farelo de } \\
\text { algodão }\end{array}$} \\
\hline & & inoculada & $\begin{array}{c}\text { não } \\
\text { nnoculada }\end{array}$ & inoculada & $\begin{array}{c}\text { não } \\
\text { inoculada }\end{array}$ & \\
\hline$\overline{M S}$ & $\%$ & 37,23 & 38,4 & $30, \overline{3}$ & 29,3 & 90,3 \\
\hline $\mathrm{EE}$ & $\% \mathrm{MS}$ & 2,31 & 2,4 & 2,6 & 2,6 & 0,7 \\
\hline MM & $\% \mathrm{MS}$ & 4,24 & 4,0 & 4,6 & 4,4 & 5,7 \\
\hline FDN & $\% \mathrm{MS}$ & 60,09 & 56,4 & 60,9 & 55,3 & 37,0 \\
\hline FDA & $\% \mathrm{MS}$ & 35,08 & 35,6 & 36,1 & 35,3 & 24,2 \\
\hline LIG & $\% \mathrm{FDN}$ & 6,29 & 6,9 & 6,3 & 6,9 & 9,3 \\
\hline $\mathrm{CNE}$ & $\% \mathrm{CHO}$ & 30,39 & 33,9 & 26,5 & 34,0 & 23,7 \\
\hline $\mathrm{CNE}$ & $\% \mathrm{MS}$ & 26,89 & 27,3 & 21,2 & 25,3 & 23,8 \\
\hline $\mathrm{CHO}$ & $\% \mathrm{MS}$ & 86,32 & 85,3 & 82,9 & 83,9 & 48,5 \\
\hline AM & $\% \mathrm{MS}$ & 22,32 & 23,3 & 15,2 & 16,2 & 0,4 \\
\hline $\mathrm{AM}$ & $\% \mathrm{CNE}$ & 73,45 & 68,8 & 57,2 & 47,7 & 1,7 \\
\hline $\mathrm{CHO}-\mathrm{SL}$ & $\% \mathrm{MS}$ & 4,57 & 4,0 & 6,1 & 9,1 & 23,4 \\
\hline $\mathrm{CHO}-\mathrm{SL}$ & $\% \mathrm{CNE}$ & 15,03 & 11,7 & 22,9 & 26,9 & 98,8 \\
\hline NIDN & $\% \mathrm{~PB}$ & 23,36 & 18,4 & 16,6 & 18,0 & 6,6 \\
\hline NIDA & $\% \mathrm{~PB}$ & 13,29 & 10,4 & 10,7 & 11,7 & 3,5 \\
\hline PB & $\% \mathrm{MS}$ & 7,13 & 8,3 & 9,9 & 9,1 & 45,0 \\
\hline PSOL & $\% \mathrm{~PB}$ & 51,15 & 57,4 & 56,4 & 54,6 & 22,2 \\
\hline NNP & $\% \mathrm{PSOL}$ & 84,30 & 78,6 & 83,2 & 94,4 & 23,7 \\
\hline DIVMS & $\% \mathrm{MS}$ & 69,04 & 65,5 & 70,5 & 69,9 & \\
\hline
\end{tabular}

MS- matéria seca; EE- extrato etéreo; MM- matéria mineral; FDN- fibra em detergente neutro; FDA- fibra em detergente ácido; LIG- lignina; CNE- carboidrato não estrutural; CHO- carboidrato; AM- amido; CHO-SL- carboidrato solủvel; NIDN- nitrogênio insolúvel em detergente neutro; NIDA- nitrogênio insolúvel em detergente ácido; PB- proteina bruta; PSOL- proteina solúvel; NNP- nitrogênio não protéico; DIVMS- digestibilidade "in vitro" da matéria seca.

De modo geral as silagens apresentaram características similares, possuindo padrões médios de qualidade. 
Altos valores da MS podem ser reponsáveis por uma diminuição na qualidade da silagem com aumentos no teor de fibra e menor concentração de carboidratos solúveis. Segundo MAHANNA (1995), menor qualidade de silagens pode ocorrer nos dois extremos: baixos teores de MS os quais aumentam os níveis de amônia, aminas e ácido butírico, e altos teores de MS, nos quais a atividade da fermentação fica reduzida, mas aumenta a dificuldade de compactação o que pode aumentar as perdas por aeração, bolores e aquecimento, levando a altos níveis de NIDA. Altos níveis de NIDA implicam em indisponibilidade de formas nitrogenadas para a fermentação microbiana ruminal. Toda forragem ensilada tem proteína indisponível como resultado tanto da fisiologia da planta como dos processos que levam ao aquecimento excessivo da massa ensilada. No entanto, WEISS et al. (1992) afirmaram que até $30 \%$ do NIDA pode ser considerado disponível.

Os teores de FDN ficaram acima de $55 \%$, o que pode ser considerado alto para silagem de milho. Mas em plantas de origem tropical geralmente esses valores são maiores do que em plantas de clima temperado. As silagens do experimento I tinham teores de FDN em torno de $50 \%$. Tanto no experimento I como no experimento II foram utilizadas as mesmas variedades de milho. Isto pode ter ocorrido devido à silagem do experimento I ter sido utilizada mais rapidamente, retirando-se de cada silo uma grande quantidade de silagem por dia. No experimento II, devido ao grande número de silos (12) envolvidos nos ensaios e o pequeno número de animais a quantidade de silagem retirada diariamente era muito pequena. Essas pequenas retiradas diárias do silo pode ter favorecido a degradação do conteúdo celular do material ensilado por microoganismos de fermentação aeróbica, o que levaria ao aumento da quantidade de parede celular. 
Entre as silagens estudadas, os dados de FDN, FDA, lignina e NIDA não caracterizaram diferenças entre alta e baixa matéria seca, com e sem inoculação.

A atividade proteolítica e as enzimas da planta podem também diminuir o valor alimentar da forragem ensilada, através da degradação de proteínas, aumentando efetivamente a quantidade de nitrogênio não protéico (NNP) na forma de amônia, nitratos, nitritos, aminoácidos livres, aminas, amidas e peptídeos (MUCK, 1988). A redução para amônia e aminas é geralmente causada pela atividade microbiana. Cinquenta por cento das proteínas da planta total podem ser degradadas por esse caminho. A adição de inóculos bacterianos ao material ensilado poderia diminuir a atividade proteolítica de microorganismos indesejáveis e a atividade enzimática da célula devido a mais rápida queda do $\mathrm{pH}$ no material ensilado.

Em silagens com elevados teores de umidade, os clostrídios podem contribuir significativamente para degradação da proteína e, como resultado, dissipar energia extra e ATP que deveriam estar disponíveis para bactéria no rúmen (Van Soest (1993) citado por MAHANNA (1995)).

A degradação da proteína da silagem resulta num aumento dos níveis de ingestão de proteína solúvel e proteína degradável, reduzindo o nível de ingestão de proteína indegradável na dieta quando comparado com outros alimentos não fermentados. No entanto, parte do nitrogênio solúvel encontrado na silagem na forma de amina, amidas, etc. pode ser aproveitado como proteína pelos ruminantes.

As quantidades de amido encontradas foram maiores para as silagens de milho com alta matéria seca do que para as de baixa matéria seca $(22,3$ e 23,3 vz 15,2 e 16,2\%). Silagem de milho com MS mais alta apresenta maior proporção de grãos, os quais são grande fonte de amido. PEREIRA (1995) encontrou variações entre diversos trabalhos, nos 
valores de amido para silagens de milho em função de diferentes proporções de grãos entre os materiais e das metologias empregadas para a sua determinação. Metodologia que emprega degradação enzimática, como a utilizada nesse trabalho, é mais precisa por quantificar somente açúcares provenientes do amido, enquanto que outros métodos, como o da digestão ácida seguida da quantificação de açúcares por reagentes, como o de Fehling, parecem determinar açúcares redutores totais, superestimando a fração amido.

A fração correspondente aos açúcares solúveis em água ( $\mathrm{CHO}$ $\mathrm{SL}$ ), ao contrário do amido, foi maior para silagens com baixos teores de MS. A presença de maior quantidade de $\mathrm{CHO}-\mathrm{SL}$ para silagens com mais baixo teor de MS pode ser outro indicativo de maior presença de grãos na silagem com alta MS, pois a quantidade de CHO-SL no grão é relativamente baixa.

\subsubsection{Avaliação da aditivação do inoculante bacteriano sobre a digestibilidade "in vivo" em bovinos.}

Nas Tabelas de 11 à 15 são apresentados resultados referentes à digestibilidade "in vivo" usando bovinos. Na Tabela 11 estão as médias dos quatro tratamentos sem levar em consideração o tipo de fornecimento. Os resultados não apresentaram diferenças significativas entre tratamentos $(P>0,05)$. Apesar de não significativos, observa-se tendência dos resultados das dietas com silagem inoculada serem maiores do que as não inoculadas, dentro do mesmo teor de MS. Na Tabela 12 estão as médias das variáveis nos diferentes níveis de fornecimento, independente do tipo de silagem. Não foi observado diferença estatística, levando-se em consideração apenas o tipo de fornecimento $(P>0,05)$. No entanto, nota-se tendência de maior digestibilidade para o fornecimento restrito. 
Tabela 11. Médias das digestibilidades das variáveis: DMS, DFDA, DFDN, DNIT e DEE, independente do nível de fornecimento.

\begin{tabular}{lcrrrr}
\hline Silagens & \multicolumn{5}{c}{ Digestibilidades das variáveis $(\%)^{1}$} \\
\hline & DMS & DFDA & DFDN & DNIT & DEE \\
\hline Alta MS inoculada & 67,9 & 54,3 & 58,1 & 76,7 & 88,7 \\
Baixa MS inoculada & 67,8 & 53,3 & 54,7 & 76,1 & 86,9 \\
Alta MS não inoculada & 67,0 & 51,3 & 54,5 & 76,1 & 83,6 \\
Baixa MS não inoculada & 66,0 & 49,7 & 52,1 & 75,4 & 81,4 \\
\hline CV (\%) & 7,4 & 11,9 & 13,1 & 5,2 & 10,0 \\
\hline
\end{tabular}

DMS: digestibilidade da matéria seca; DFDA: da fibra em detergente ácido; DFDN: da fibra em detergente neutro; DNIT: do nitrogênio; DEE: do extrato etéreo.

Tabela 12. Médias das variáveis nos diferentes níveis de fornecimento, independente do tipo de silagem.

\begin{tabular}{cccccc}
\hline \multirow{2}{*}{ Dietas } & \multicolumn{5}{c}{ Médias das Variáveis (\%) } \\
\cline { 2 - 6 } & DMS & DFDA & DNDF & DNIT & DEE \\
\hline $60 \mathrm{~g} / \mathrm{Kg} \mathrm{PV} \mathrm{P}^{0,75}$ & 67,4 & 52,5 & 55,0 & 76,2 & 86,1 \\
$80 \mathrm{~g} / \mathrm{Kg} \mathrm{PV}^{0,75}$ & 67,0 & 52,0 & 54,7 & 76,0 & 84,0 \\
\hline
\end{tabular}

DMS: digestibilidade da matéria seca; DFDA: da fibra em detergente ácido; DFDN: da fibra em detergente neutro; DNIT: do nitrogênio; DEE: do extrato etéreo.

Nas tabelas 13 e 14 são apresentadas as médias das variáveis estudadas, com fornecimento de 60 e $80 \mathrm{~g} / \mathrm{Kg} \mathrm{PV}^{0,75}$, respectivamente.

A interação tratamento e nível de fornecimento não foi significativa para as variáveis estudadas $(\mathrm{P}>0,05)$. Apesar de não significativa, observa-se tendência de maior digestibilidade da fibra (DFDA， DFDN) para as silagens inoculadas, principalmente com fornecimento mais alto. Estes dados comprovariam os resultados do experimento I, onde foi encontrado maior digestibilidade da fibra em ensaios com carneiros. A maior digestibilidade da fibra causaria no rúmen maior produção de ácido acético, o que poderia levar a maior produção de gordura no leite. 
Tabela 13. Médias das digestibilidades das variáveis: DMS, DFDA, DFDN, DNIT e DEE, com fornecimento de $60 \mathrm{~g} / \mathrm{Kg} \mathrm{PV}^{0,75}$.

\begin{tabular}{lrrrrr}
\hline \multicolumn{1}{c}{ Silagens } & \multicolumn{5}{c}{ Médias das Variáveis (\%) } \\
\cline { 2 - 6 } & DMS & DFDA & DNDF & DNIT & DEE \\
\hline Alta MS inoculada & 67,3 & 50,7 & 51,9 & 75,9 & 80,1 \\
Baixa MS inoculada & 68,1 & 55,0 & 58,2 & 76,7 & 88,2 \\
Alta MS não inoculada & 67,0 & 52,1 & 52,3 & 75,2 & 82,8 \\
Baixa MS não inoculada & 67,1 & 52,1 & 56,9 & 76,2 & 85,0 \\
\hline
\end{tabular}

DMS: digestibilidade da matéria seca; DFDA: da fibra em detergente ácido; DFDN: da fibra em detergente neutro; DNIT: do nitrogênio; DEE: do extrato etéreo.

De acordo com McDONALD et al. (1991), diversos trabalhos têm demonstrado que silagens tratadas com inoculante são mais digestíveis do que as não tratadas. Em outros casos, o aditivo não teve efeito sobre a digestibilidade ou teve um efeito negativo.

Tabela 14. Médias das digestibilidades das variáveis: DMS, DFDA, DFDN, DNIT e DEE, com fornecimento de $80 \mathrm{~g} / \mathrm{Kg} \mathrm{PV}^{0,75}$.

\begin{tabular}{lccccc}
\hline \multirow{1}{*}{ Silagens } & \multicolumn{5}{c}{ Médias das Variáveis (\%) } \\
\cline { 2 - 6 } & DMS & DFDA & DNDF & DNIT & DEE \\
\hline Alta MS inoculada & 68,6 & 56,0 & 57,1 & 77,5 & 82,7 \\
Baixa MS inoculada & 67,4 & 53,6 & 58,1 & 75,5 & 89,0 \\
Alta MS inoculada & 66,9 & 50,6 & 51,9 & 77,1 & 84,4 \\
Baixa MS não inoculadaS & 64,9 & 47,3 & 52,6 & 74,6 & 88,7 \\
\hline
\end{tabular}

DMS: digestibilidade da matéria seca; DFDA: da fibra em detergente ácido; DFDN: da fibra em detergente neutro; DNIT: do nitrogênio; DEE: do extrato etéreo.

Apesar dos inoculantes bacterianos afetarem a concentração e digestibilidade da fibra da silagem, não está claro que mecanismos químicos, físicos ou biológicos estariam envolvidos nas mudanças da digestibilidade da fibra.

Os resultados de digestibilidade da fibra variaram de 47,3 a 56,0 para DFDA e 51,9 a $58,1 \%$ para DFDN. Esta variação pode afetar o 
conteúdo de energia da ração, a produção de proteína microbiana, a predição laboratorial do conteúdo energético e a ingestão da MS.

A digestibilidade da fibra da silagem de milho pode ser afetada pela maturidade na colheita, genética e condições ambientais. As quantidades de grãos e amido na forragem aumentam com o aumento na maturidade e o conteúdo de açúcar diminui. A parede celular total pode decrescer devido a um aumento no conteúdo de grão.

A fermentação ruminal medida após $24 \mathrm{~h}$ em técnicas "in situ" foi significativamente reduzida em cada estágio com aumento da maturidade (HUNT et al., 1989).

SANDERSON (1993) afirmou que a inoculação com bactérias láticas não afetou a deteriorização aeróbica ou digestibilidade da fibra de silagem de milho. Variáveis resultantes a partir destes estudos e outros efeitos relativos a estabilidade aeróbica e digestibilidade da fibra da silagem sugerem que os inoculantes bacterianos deveriam ser vistos primariamente como auxiliadores da fermentação.

$\mathrm{Na}$ Tabela 15 são apresentados os valores de digestibilidade da lignina (DLIG), do nitrogênio insolúvel em detergente neutro (DNIDN) e do nitrogênio insolúvel em detergente ácido (DNIDA) para dietas à base de silagens com alta e baixa MS, com e sem inoculante. Os valores não apresentaram respostas significativas para lignina e NIDN. Para NIDA foi encontrado maior digestibilidade em dietas à base de silagem inoculada com alta MS e alta MS não inoculada. Os dados da Tabela 15 apresentaram uma grande variação (alto $\mathrm{CV}$ ), demonstrando uma grande imprecisão na avaliação. Os valores encontrados para digestibilidade da lignina possuem média de $7,4 \%$ enquanto que VAN SOEST (1982) apresenta valores de digestibilidade aparente da lignina variando de 1 a $2 \%$. Este mesmo autor afirma que alimentos que não sofreram aquecimento possuem de 5 a $15 \%$ de nitrogênio indisponivel, sendo que esta proporção pode aumentar através de manuseio inadequado da 
amostra. A indefinição da composição da lignina e de como ela estaria ligada a outros componentes, tais como o nitrogênio, podem ser responsáveis pela grande variação observada na Tabela 12 .

Tabela 15. Médias das digestibilidades das variáveis: lignina, NIDN e NIDA, independente do nível de fornecimento.

\begin{tabular}{lccc}
\hline Silagens & \multicolumn{3}{c}{ Digestibilidades das variáveis (\%) } \\
\cline { 2 - 4 } & Lignina & NIDN & NIDA $^{2}$ \\
\hline Alta MS inoculada & 9,9 & 35,8 & $33,4 \mathrm{a}$ \\
Baixa MS inoculada & 5,9 & 31,5 & $11,6 \mathrm{~b}, \mathrm{c}$ \\
Alta MS não inoculada & 12,0 & 29,3 & $22,9 \mathrm{a}, \mathrm{b}$ \\
Baixa MS não inoculada & 1,8 & 28,5 & $1,4 \mathrm{c}$ \\
\hline CV $(\%)$ & 224,8 & 55,0 & 98,7 \\
\hline NIDN: nitrogênio insolúvel em detergente neutro; NIDA: nitrogênio insolúvel em \\
detergente ácido. \\
2 Na mesma coluna, médias assinaladas por letras distintas diferiram entre si, pelo \\
teste de Tukey $(\mathrm{P}<0,05)$.
\end{tabular}

\subsubsection{Avaliação da aditivação do inoculante bacteriano sobre a taxa de passagem de dietas à base de silagem de milho com alta e baixa matéria seca, com e sem inoculante.}

As taxas de passagem das dietas estudadas, estimadas a partir de amostras de fezes, são apresentadas na Tabela 16. Não houve efeito do inóculo e/ou da matéria seca sobre a taxa de passagem das dietas $(\mathrm{P}>0,05)$. GOESTCH \& OWENS (1985) avaliaram o efeito do local (rúmen, duodeno, íleo e reto) de amostragem para a estimativa da taxa de passagem de líquidos e sólidos. Os mesmos concluíram que a coleta no reto foi a mais adequada para estimar a taxa de passagem de partículas.

Para todas as dietas as maiores concentrações de cromo foram observadas entre 28 e $36 \mathrm{~h}$. PEREIRA (1995), trabalhando com dietas à base de silagem de milho com diferentes proporções de concentrados, encontrou resultados semelhantes. O autor cita ainda que coletas acima de 
$80 \mathrm{~h}$ apresentaram grande variação entre repetições e ficaram abaixo da faixa ideal de leitura do espectrofotômetro.

Tabela 16. Taxa de passagem das silagens de milho com alta e baixa matéria seca (\%), inoculada e sem inoculação, estimadas a partir de amostras de fezes de bovinos.

\begin{tabular}{|c|c|c|c|c|}
\hline \multirow[t]{2}{*}{ Animal } & \multicolumn{2}{|c|}{ Alta matéria seca } & \multicolumn{2}{|c|}{ Baixa matéria seca } \\
\hline & Inoculada & Não inoculada & Inoculada & Não inoculada \\
\hline A1 & 1,79 & 3,72 & 2,63 & 2,17 \\
\hline A2 & 3,11 & 3,98 & 2,04 & 3,28 \\
\hline A3 & 2,08 & 2,03 & 2,08 & 1,74 \\
\hline Média & 2,33 & 3,24 & 2,25 & 2,40 \\
\hline
\end{tabular}

De acordo com revisão de PEREIRA (1995) os principais fatores que afetam a taxa de passagem são o nível de ingestão e proporção de concentrado na dieta. Possíveis melhorias na conservação da silagem provocadas pelo inoculante levariam a um aumento da ingestão e consequentemente a um aumento da taxa de passagem. Neste estudo, os níveis de ingestão pelos animais foram os mesmos $\left(70 \mathrm{~g} / \mathrm{kg} \mathrm{PV}^{0,75}\right)$ em todas as dietas. No ensaio de confinamento no experimento 1 , porém, não houve diferenças na ingestão de MS entre silagens inoculada e não inoculada.

As taxas de passagem obtidas neste ensaio foram utilizadas para calcular a degradabilidade efetiva das dietas estudadas.

\subsubsection{Avaliação da aditivação do inoculante bacteriano na degradabilidade "in situ" de silagens inoculadas.}

Para determinação dos valores obtidos na análise de degradação "in situ" não foi considerado o tempo de colonização (lag time) do alimento pelas bactérias do rúmen. PEREIRA (1995) não encontrou efeito 
significativo do uso de lag time sobre a degradabilidade potencial para silagem de milho. A consideração do lag time determina maiores valores para a fração solúvel (A) do alimento.

$\mathrm{Na}$ Tabela 17 são apresentados os valores da fração solúvel (A), potencialmente degradável (B), e indegradável (C) da matéria seca estimados das silagens de milho com alta e baixa MS, inoculada e sem inoculação. A fração solúvel (A) foi obtida somente pela lavagem dos sacos em água a $39^{\circ} \mathrm{C}$ por 15 minutos e, portanto, não sofreu efeito da dieta ou do animal. As frações potencialmente degradável (B) e a indegradável (C) foi obtida através da amostragem com animais. Os dados não apresentaram diferenças significativas a nivel de $5 \%$ de probabilidade.

As silagens apresentaram solubilidade da MS variando de 28,0$32,7 \%$, não caracterizando diferenças entre inoculadas e não inoculadas, alta e baixa MS. PEREIRA (1995) encontrou resultados médios para fração A da MS de silagem de milho de 20\%. SUSMEL et al. (1990) mostraram resultados da ordem de $26 \%$, enquanto que os dados de VALADARES FILHO et al. (1991) apresentaram a fração A da MS com $16 \%$.

Valores mais altos para fração A e menores para fração B encontrados neste trabalho comparativamente com outros podem ser devido a solubilidade de parte do amido em água quente. Metodologias descritas por PETIT et al. (1994) e THIAGO (1994) utilizam água fria na determinação da fração A.

De acordo com NOCEK (1988) pequenas variações encontradas na fração A podem ser atribuidas a composição do material, enquanto que grandes variações devem-se a perdas de pequenas partículas durante o processo de lavagem. Estas perdas ocorrem devido à porosidade dos sacos, tamanho de partícula e diferentes formas de determinação da fração A (Tabela 10). 
Em silagens inoculadas poderia ocorrer aumento da fração $\mathrm{A}$, como consequência do aumento nos teores de carboidratos solúveis resultantes da maior eficiência no processo de fermentação no silo, resultado não verificado neste estudo.

Tabela 17 Frações solúvel (A), potencialmente degradável (B) e indegradável (C) da matéria seca estimadas a partir das silagens de milho avaliadas com alta e baixa matéria seca, inoculada e não inoculada.

\begin{tabular}{|c|c|c|c|}
\hline \multirow[t]{2}{*}{ Silagens } & \multicolumn{3}{|c|}{ Frações da matéria seca } \\
\hline & $A(\%)$ & $\mathrm{B}(\%)$ & $\mathrm{C}(\%)$ \\
\hline Matéria seca alta, inoculada & 30,8 & 40,1 & 29,0 \\
\hline Matéria seca alta, não inoculada & 28,0 & 46,8 & 25,2 \\
\hline Matéria seca baixa, inoculada & 28,7 & 44,6 & 26,6 \\
\hline Matéria seca baixa, não inoculada & 32,7 & 42,6 & 24,7 \\
\hline CV $(\%)$ & $1^{*}$ & 8,7 & 14,4 \\
\hline
\end{tabular}

1* Dados obtidos de uma única observação

Os valores relativos à fração solúvel (A), potencialmente degradável (B) e indegradável (C) da proteína bruta das silagens estudadas são apresentados na Tabela 18.

Os valores da fração $A$ apesar de altos concordam com os obtidos por PEREIRA (1995) que encontrou $62,61 \%$ de solubilidade em silagem de milho. Estes valores podem ser justificados pelo fato da PSOL da silagem corresponder em média a mais de $50 \%$ da $\mathrm{PB}$, sendo que em torno de $80 \%$ da PSOL era NNP que é altamente solúvel.

Os dados da fração $C$ apresentam-se muito altos. Os valores de NIDN não foram corrigidos pelo NIDA, no experimento II, o que pode ter contribuido para o aumento da fração $C$. Outro fator que pode ter influído é a contaminação das amostras retiradas do rúmen por microorganismos ruminais. Tal contaminação é muito comum no uso desta metodologia. VALADARES FILHO (1994) chama a atenção que os valores da fração B 
ficam subestimados quando não ocorre correção para a contaminação da proteína microbiana.

Tabela 18. Frações solúvel (A), potencialmente degradável (B) e indegradável $(C)$ da proteína bruta, nas silagens de milho com alta e baixa matéria seca, inoculada e sem inoculação.

\begin{tabular}{|c|c|c|c|}
\hline \multirow[t]{2}{*}{ Silagens } & \multicolumn{3}{|c|}{ Frações da proteína bruta } \\
\hline & $\mathrm{A}(\%)$ & B (\%) & $\mathrm{C}(\%)$ \\
\hline Matéria seca alta, inoculada & 53,4 & 26,2 & 20,4 \\
\hline Matéria seca alta, não inoculada & 63,6 & $19,4 \mathrm{I}$ & 17,0 \\
\hline Matéria seca baixa, inoculada & 60,0 & 21,21 & 18,8 \\
\hline Matéria seca baixa, não inoculada & 60,8 & 20,51 & 18,7 \\
\hline CV $(\%)$ & $2^{*}$ & 9,8 & 11,5 \\
\hline
\end{tabular}

$1 \mathrm{Na}$ mesma coluna, médias assinaladas por letras distintas diferiram entre si, pelo teste de Tukey $(P<0.05)$;

2* Dados obtidos de uma única observação

A silagem inoculada com alta MS apresentou maior valor da fração $B$ em relação às demais $(P<0,05)$. Isto pode ser indicativo de que os componentes nitrogenados da parede celular desta silagem tenham sido menos liberados devido a menor processo de degradação da silagem no interior do silo. Os valores da fração $\mathrm{A}$ desta silagem conduzem a esta afirmação por serem menores do que os demais.

KEADY et al. (1994), estudando o efeito de inoculante bacteriano na degradabilidade de silagem constataram que tratamento com inoculante melhorou a digestibilidade das silagens resultantes e aumentou a degradabilidade ruminal de nitrogênio, aumentando o valor da fração solúvel (A) do nitrogênio $(\mathrm{N})$, e o valor total da degradabilidade de $\mathrm{N}$.

O aumento na solubilidade do nitrogênio é uma indicação de aumento de proteólise no silo, o qual é usualmente associado com a atividade de protease da planta. Aumento na solubilidade de nitrogênio pode ser resultado de modificações na estrutura da parede celular, a partir 
de fontes de $\mathrm{N}$ de baixa degradação, pois este pode ser liberado pela degradação de carboidratos estruturais. Assim, o efeito do tratamento inoculado sobre os componentes da parede celular, indicado pelas mudanças na digestibilidade da fibra, poderia ter resultado em aumento da fração solúvel de $\mathrm{N}$ e da degradabilidade total. No entanto, não foram comprovadas, neste trabalho diferenças entre digestibilidade $\mathrm{e}$ degradabilidade da MS.

As Tabelas 19 e 20 apresentam os resultados das frações (A), (B) e (C) do nitrogênio insolúvel em detergente neutro (NIDN) e da fibra em detergente neutro (FDN), respectivamente, para as silagens estudadas. Não foram observadas diferenças significativas entre os tratamentos avaliados $(\mathrm{P}>0,05)$.

Estudando gramínea de baixa MS inoculada, KEADY \& STEEN (1994) concluíram que o inoculante melhorou a fermentação da silagem, mas teve pouco efeito sobre a ingestão de silagem para animais confinados. O aditivo teve efeito positivo também sobre a degradabilidade ruminal do FDA, mas não teve efeito sobre degradabilidade ruminal da MS e FDN.

Tabela 19. Frações solúvel (A), potencialmente degradável (B) e indegradável (C) do nitrogênio insolúvel em detergente neutro, nas silagens de milho com alta e baixa matéria seca, inoculada e sem inoculação

\begin{tabular}{|c|c|c|c|}
\hline \multirow[t]{2}{*}{ Silagens } & \multicolumn{3}{|c|}{ Frações do nitrogênio insolúvel } \\
\hline & A (\%) & B $(\%)$ & $\mathrm{C}(\%)$ \\
\hline Matéria seca alta, inoculada & 24,6 & 32,0 & 43,4 \\
\hline Matéria seca alta, não inoculada & 14,3 & 42,9 & 42,7 \\
\hline Matéria seca baixa, inoculada & 9,6 & 35,7 & 54,7 \\
\hline Matéria seca baixa, não inoculada & 10,4 & 44,0 & 45,6 \\
\hline $\mathrm{CV}(\%)$ & $1^{*}$ & 13,0 & 10,8 \\
\hline
\end{tabular}


O aumento da fração solúvel (A) da fibra em detergente a partir do tratamento inoculado pode ser devido a vários fatores: 1. ao rápido decréscimo do $\mathrm{pH}$ da silagem, resultando numa fermentação mais eficiente e preservação de mais componentes solúveis da frações da fibra; 2 . alguma degradação enzimática, pelo inoculante ou encorajado pelo mesmo, na ensilagem; 3. aumento da hidrólise ácida de carboidratos estruturais da planta, tais como celulose, hemicelulose e pectina, como resultado de maior queda do $\mathrm{pH}$ (MORRISON, 1979).

Tabela 20. Frações solúvel (A), potencialmente degradável (B) e indegradável (C) da fibra em detergente neutro, nas silagens de milho com alta matéria seca, com e sem inoculação.

\begin{tabular}{|c|c|c|c|}
\hline \multirow[t]{2}{*}{ Silagens } & \multicolumn{3}{|c|}{$\begin{array}{c}\text { Frações da fibra em detergente } \\
\text { neutro }\end{array}$} \\
\hline & $\mathrm{A}(\%)$ & B (\%) & C $(\%)$ \\
\hline Matéria seca alta, inoculada & 22,9 & 41,2 & 35,9 \\
\hline Matéria seca alta, não inoculada & 8,9 & 56,5 & 34,6 \\
\hline Matéria seca baixa, inoculada & 15,7 & 48,6 & 35,7 \\
\hline Matéria seca baixa, não inoculada & 17,6 & 48,1 & 34,3 \\
\hline $\mathrm{CV}(\%)$ & $1^{*}$ & 10,5 & 14,5 \\
\hline
\end{tabular}

Os dados referentes às degradabilidades efetivas e potenciais, e as taxas de degradações da matéria seca e da proteína bruta das silagens de milho avaliadas encontram-se nas tabelas 21 e 22 . Os tratamentos não diferiram significativamente entre si para os parâmetros estudados.

Os valores de degradação efetiva (DE) foram estimados a partir das taxas de passagem obtidas no decorrer do próprio ensaio (Tabela 16). A variação observada para degradação efetiva da MS foi de $54,1 \%$ a $60,6 \%$ e para taxa de degradação foi de 4,0 a $4,8 \%$. Para proteína bruta, a variação da degradação efetiva ocorreu entre 67,7 a $73,1 \%$, enquanto que a taxa de degradação variou de 2,87 a $3,54 \%$. 
Tabela 21. Degradabilidade efetiva (DE) e potencial (DP), e taxa de degradação (TD) da matéria seca das silagens de milho avaliadas.

\begin{tabular}{lrrr}
\hline \multicolumn{1}{c}{ Silagens } & \multicolumn{3}{c}{ Matéria seca } \\
\cline { 4 - 5 } \cline { 3 - 4 } Matéria seca alta, inoculada & DE (\%) & DP (\%) & TD (\%) \\
Matéria seca alta, não inoculada & 57,7 & 69,2 & 4,8 \\
Matéria seca baixa, inoculada & 54,1 & 72,1 & 4,0 \\
Matéria seca baixa, não inoculada & 57,9 & 71,1 & 4,1 \\
\hline CV (\%) & 60,6 & 73,3 & 4,4 \\
\hline
\end{tabular}

VALADARES FILHO et al. (1991) mostraram que a degradação efetiva pode sofrer grande variação dependendo do valor da taxa de passagem utilizada para o cálculo. Os autores encontraram valores de degradação efetiva da MS e PB de 42,9 e $74,9 \%$ respectivamente, para uma taxa de degradação $3 \% / \mathrm{h}$, e valores de 55,3 de DEMS e $30,6 \%$ DEPB para taxas de passagem de $4 \% / h$.

VALADARES FILHO (1994) obteve dados médios de diversos ensaios de $33,4 \%$ para DEMS e $47,7 \%$ para DEPB com taxa de passagem de $5 \% / \mathrm{h}$.

Tabela 22. Degradabilidade efetiva (DE) e potencial (DP), e taxa de degradação (TD) da proteína bruta das silagens de milho com alta e baixa matéria seca, inoculada e sem inoculação.

\begin{tabular}{|c|c|c|c|}
\hline \multirow[t]{2}{*}{ Silagens } & \multicolumn{3}{|c|}{ Proteína bruta } \\
\hline & $\mathrm{DE}(\%)$ & DP (\%) & TD (\%) \\
\hline Matéria seca alta, inoculada & 67,7 & 75,4 & 2,9 \\
\hline Matéria seca alta, não inoculada & 72,7 & 80,4 & 2,9 \\
\hline Matéria seca baixa, inoculada & 72,7 & 79,1 & 3,3 \\
\hline Matéria seca baixa, não inoculada & 73,1 & 79,3 & 3,5 \\
\hline $\mathrm{CV}(\%)$ & 2,7 & 2,36 & 30,8 \\
\hline
\end{tabular}

PEREIRA (1995) obteve valores para taxa de degradação de $2,43 \% / \mathrm{h}$ para MS e $3,76 \% / \mathrm{h}$ para proteína bruta para silagem de milho em 
dietas com $60 \%$ de volumoso (silagem de milho) e $40 \%$ de concentrado. Neste trabalho foram obtidos taxas mais altas para degradação da matéria seca.

$\mathrm{Na}$ tabelas 23 e 24 constam os resultados da degradabilidade efetiva (DE) e potencial (DP) e da taxa de degradação (TD) para nitrogênio insolúvel em detergente neutro (NIDN) e para fibra em detergente neutro (FDN). Não foram observadas diferenças significativas entre silagens para DP e TD $(P>0,05)$. Os valores de degradabilidade efetiva (DE) do NIDN para silagem com alta MS inoculada e baixa MS não inoculada foram maiores do que nos outros tratamentos $(P<0,05)$.

Tabela 23. Degradabilidade efetiva (DE) e potencial (DP), e taxa de degradação (TD) do nitrogênio insolúvel em detergente neutro, das silagens de milho com alta e baixa matéria seca, inoculada e sem inoculação.

\begin{tabular}{|c|c|c|c|}
\hline \multirow[t]{2}{*}{ Silagens } & \multicolumn{3}{|c|}{ Nitrogênio em detergente neutro } \\
\hline & $\mathrm{DE}(\%)$ & $\mathrm{DP}(\%)$ & TD (\%) \\
\hline Matéria seca alta, inoculada & $44,9 \mathrm{a}$ & 53,7 & 4,5 \\
\hline Matéria seca alta, não inoculada & $36,0 \mathrm{~b}, \mathrm{c}$ & 52,7 & 3,5 \\
\hline Matéria seca baixa, inoculada & $30,6 \mathrm{c}$ & 40,8 & 4,0 \\
\hline Matéria seca baixa, não inoculada & $39,6 \mathrm{a}$ & 51,2 & 4,4 \\
\hline $\mathrm{CV}(\%)$ & 10,0 & 8,8 & 44,6 \\
\hline
\end{tabular}

${ }^{1} \mathrm{Na}$ mesma coluna, médias assinaladas por letras distintas diferiram entre si, pelo teste de Tukey $(P<0.05)$.

Os dados de degradabilidade efetiva do FDN mostraram-se inferiores aos demais para a silagem não inoculada ecom alta MS. Apesar das diferenças significativas de degradação efetiva entre algumas silagens estudadas, não ficou demonstrada uma tedência de superioridade de um tratamento sobre os demais. 
Nos dados observados, em alguns casos, existe uma grande diferença numérica entre tratamentos apesar de não ser significante do ponto de vista estatístico. Isto pode ter sido provocado pelo pequeno número de animais envolvidos no ensaio de degradação "in situ" e o alto CV.

Tabela 24. Degradabilidade efetiva (DE) e potencial (DP), e taxa de degradação (TD) da fibra em detergente neutro, das silagens de milho avaliadas.

\begin{tabular}{lcccc}
\hline \multicolumn{1}{c}{ Silagens } & \multicolumn{3}{c}{ Fibra em detergente neutro } \\
\cline { 3 - 5 } \cline { 3 - 5 } & DE (\%) & DP (\%) & TD (\%) \\
\hline Matéria seca alta, inoculada & & $48,8 \mathrm{a}$ & 61,1 & 4,1 \\
Matéria seca alta, não inoculada & & $37,2 \mathrm{~b}$ & 59,8 & 3,2 \\
Matéria seca baixa, inoculada & & $45,2 \mathrm{a}$ & 59,7 & 3,7 \\
Matéria seca baixa, não inoculada & & $50,0 \mathrm{a}$ & 63,7 & 4,8 \\
\hline CV (\%) & 7,6 & 34,9 & 7,8 \\
\hline
\end{tabular}

${ }^{1} \mathrm{Na}$ mesma coluna, médias assinaladas por letras distintas diferiram entre si, pelo teste de Tukey $(\mathrm{P}<0.05)$.

Nas Tabelas de 25 a 28 são apresentados dados de degradação da fração A, B, C, taxa de degradação, degradabilidade efetiva e potencial na MS e PB do farelo de algodão.

Tabela 25. Frações solúvel (A), potencialmente degradável (B) e indegradável (C) da matéria seca do farelo de algodão, nas dietas avaliadas.

\begin{tabular}{|c|c|c|c|}
\hline \multirow[t]{2}{*}{ Dietas } & \multicolumn{3}{|c|}{ Frações da matéria seca ${ }^{\prime}$} \\
\hline & $\mathrm{A}(\%)$ & $\mathrm{B}(\%)$ & $\mathrm{C}(\%)$ \\
\hline Matéria seca alta, inoculada & 28,6 & 49,7 & $21,7 \mathrm{a}$ \\
\hline Matéria seca alta, não inoculada & 28,6 & 53,2 & $18,1 \mathrm{~b}$ \\
\hline Matéria seca baixa, inoculada & 28,6 & 53,6 & $17,8 \mathrm{~b}$ \\
\hline Matéria seca baixa, não inoculada & 28,6 & 53,8 & $17,6 \mathrm{~b}$ \\
\hline $\mathrm{CV}(\%)$ & $2 *$ & 1,4 & 3,9 \\
\hline
\end{tabular}


A fração A apresentou os mesmos valores para todos os tratamentos, pois o farelo de algodão foi o mesmo em todas as dietas, ficando a variação somente para as silagens (Tabelas 25 e 26). Os valores encontrados para a fração solúvel foram de $28,6 \%$ para MS e 45,7\% para PB. Estes valores são concordantes com os encontrados por PEREIRA (1995), que trabalhando com farelo de agodão, encontrou valores médios de $25,12 \%$ para MS e $41,48 \%$ para $P B$ na fração $A$. Porém, estes dados obtidos podem ser considerados altos quando comparados com outros valores encontrados na literatura. VALADARES FILHO et al. (1991), trabalhando com digestibilidade "in situ" de farelo de algodão, observaram valores variando de 12 a $20 \%$ para MS e de 20 a $28 \%$ para PB. A discrepância entre os resultados pode ser justificada através das diferentes metodologias empregadas. Sacos de náilon com porosidades diferentes podem provocar mais ou menos variação entre as frações $A$ de um mesmo alimento. O aumento da porosidade pode provocar perdas de partículas sólidas, o que superestimaria a fração $\mathrm{A}$.

A fração $B$ também não apresentou diferença significativa $(\mathrm{P}>0,05)$ tanto para MS com para PB (Tabelas 25 e 26). Foi verificado maior fração $\mathrm{C}$ em dietas à base de silagem com alta MS inoculada ( $\mathrm{P}<$ $0,05)$.

Tabela 26. Frações solúvel (A), potencialmente degradável (B) e indegradável (C) da proteína bruta do farelo de algodão, nas dietas avaliadas.

\begin{tabular}{llccc}
\hline \multicolumn{1}{c}{ Dietas } & & \multicolumn{2}{c}{ Frações da proteína bruta } \\
\cline { 4 - 5 } \cline { 4 - 5 } \cline { 4 - 5 } Matéria seca alta, inoculada & A (\%) & B (\%) & C (\%) \\
Matéria seca alta, não inoculada & & 45,7 & 47,4 & 6,9 \\
Matéria seca baixa, inoculada & & 45,7 & 49,0 & 5,2 \\
Matéria seca baixa, não inoculada & & 45,7 & 49,6 & 4,7 \\
\hline CV (\%) & & $1^{*}$ & 49,5 & 4,7 \\
\hline 1* Dados obtidos de uma única observação. & & &
\end{tabular}


$\mathrm{Na}$ Tabela 27 observa-se a maior degradabilidade potencial para as silagens com baixa MS, independente da inoculação, e alta matéria seca não inoculado $(\mathrm{P}<0,05)$. Estes resultados não caracterizam melhorias obtidas a partir da inoculação das silagens ou do teor de MS das mesmas. Os demais parâmetros estudados não apresentaram diferenças significativas $(\mathrm{P}>0,05)$. Os valores de $\mathrm{DE}$ para $\mathrm{MS}$ variaram de 63,8 a $68,8 \%$, muito acima dos encontrados por VALADARES FILHO et al (1991), de 36,6\% para uma taxa de passagem de 3\%/h. PEREIRA (1995), encontrou valores de DE para MS da ordem de $59,2 \%$, dados bem mais próximos dos obtidos neste estudo.

Tabela 27 Degradabilidade efetiva (DE) e potencial (DP), e taxa de degradação (TD) da matéria seca do farelo de algodão, nas dietas avaliadas.

\begin{tabular}{|c|c|c|c|}
\hline \multirow[t]{2}{*}{ Dietas } & \multicolumn{3}{|c|}{ Matéria seca $^{I}$} \\
\hline & DE (\%) & DP (\%) & TD (\%) \\
\hline Matéria seca alta, inoculada & 64,5 & $75,4 \mathrm{~b}$ & 6,1 \\
\hline Matéria seca alta, não inoculada & 63,8 & $79,0 \mathrm{a}$ & 6,1 \\
\hline Matéria seca baixa, inoculada & 67,4 & 78,8 a & 5,8 \\
\hline Matéria seca baixa, não inoculada & 68,8 & 80,5 a & 7,0 \\
\hline$\overline{\mathrm{CV}}(\%)$ & 4,5 & 1,0 & 7,7 \\
\hline
\end{tabular}

Na Tabela 28 são apresentados os resultados de DE, DP e TD da proteína bruta do farelo de algodão utilizados nas dietas experimentais. Não foi encontrado diferenças significativas $(P>0,05)$.

Estes resultados, de um modo geral, são próximos aos obtidos por PEREIRA (1995) e bem maiores do que os encontrados por VALADARES FILHO et al. (1991) e VILELA (1994). A discrepância entre os valores pode ser explicado pela diferença na metodologia empregada nos trabalhos e/ou pelo teor de proteína do farelo de algodão. Nos trabalhos de VILELA (1994) o teor de PB foi apenas de $36 \%$ enquanto neste trabalho foi de $48 \%$. Além disso, ensaios desenvolvidos 
com nelore tendem a apresentar valores de degradabilidade efetiva do nitrogênio mais eficiente.

Tabela 28 Degradabilidade efetiva (DE) e potencial (DP), e taxa de degradação (TD) da proteína bruta do farelo de algodão, nas dietas avaliadas.

\begin{tabular}{|c|c|c|c|}
\hline \multirow[t]{2}{*}{ Dietas } & \multicolumn{3}{|c|}{ Proteína bruta } \\
\hline & DE (\%) & DP (\%) & TD (\%) \\
\hline Matéria seca alta, inoculada & 78,6 & 88,7 & 5,6 \\
\hline Matéria seca alta, não inoculada & 79,2 & 92,6 & 6,8 \\
\hline Matéria seca baixa, inoculada & 82,8 & 93,2 & 6,7 \\
\hline Matéria seca baixa, não inoculada & 81,4 & 92,4 & 6,5 \\
\hline$\overline{C V}(\%)$ & 5,0 & 1,9 & 23,1 \\
\hline
\end{tabular}

Pesquisas devem ser direcionadas para melhorar os métodos de caracterização das quantidades de proteína e energia, particularmente ligada a parede celular de silagens. Parece evidente que existe necessidade de entender o mecanismo pelo qual os tratamentos com inoculante afetam o desempenho animal a fim de aumentar o potencial desses aditivos biológicos. Não se pode esquecer também a importância de se estudar a microflora epífita no que diz respeito a sua magnitude, estado metabólico e população para auxiliar na predição da real necessidade de se aditivar uma forragem. O suprimento e disponibilidade de substrato também deve ser considerado. A chave dessas questões está na avaliação dos primeiros estágios de ensilagem quando a taxa e o tipo de fermentação influenciam marcadamente a atividade enzimática da planta $e$ a atividade microbiológica intermediária. O ideal, portanto, é descobrir novas gerações de inoculantes que possam ser eficientes tanto em influenciar as características de fermentação como o desempenho animal mesmo em condições de forragem com alta umidade. 


\section{CONCLUSÕES}

- As estirpes de bactérias homofermentativas adicionadas às silagens de milho não tiveram efeito consistente no processo de fermentação sob as condições empregadas;

-Melhorias na digestibilidade da fibra observadas "in vivo", usando carneiros, não proporcionaram aumento no desempenho de novilhos da raça nelore confinados alimentados com dieta à base de silagem inoculada;

-Os valores da digestibilidade "in vivo", usando bovinos, não mostraram diferenças entre silagens tratadas e sem inoculação;

-Degradação "in situ", bem como taxa de passagem de dietas à base de silagem de milho, com alta e baixa matéria seca, com e sem inoculação não caracterizaram superioridade de um tratamento sobre os demais. 


\section{REFERÊNCIAS BIBLIOGRÁFICAS}

A.O.A.C. Official methods of analysis. Association of Official Agricultural Chemists. (12a ed) Washington, D.C., 1975.

AGUILERA, G. R. Dynamics of the fermentation of tropical grass silage. 1. Elephant grass ( $P$. purpureum) without additives. Cuban Journal of Agricultural Science, 9: 227-235, 1975.

ANDERSON, R.; GRACEY, H.I.; KENNDY, S.J.; UNSWORTH, E.F.; STEEN, WJ. Evaluation studies in the development of a commercial bacterial inoculant as an additive for grass silage. 1. Using pilot-scale tower silos. Grass and Forage Science, Oxford, A. Younger, 44:361-369. 1989.

CASTLE, M. E. Conclusions and future prospects. proceedings of the eurobac conference. Grass and Forage Reports, Swedish University of Agricultural Sciences, 3: 184-188. 1990. (resumo)

CATCHPOOLE, V. R. \& HENZEL, E. F. Silage and silage-making from tropical herbage species. Herbage, 41:213-221, (1971) (resumo).

FENTON, M. P. An investigation into the sources of lactic acid bacteria in grass silage. Journal of Applied Bacteriology, Reading, 62: 181188, 1987. 
FITZSIMMONS, A.; DUFFNER, F.; CURTIN, D.; BROPHY, G.; O'KIELY, P.; O'CONNELL, M. assessment of pediococcus acidilactici as a potential silage inoculant. Applied and Enviromental Microbiology, Baltimore, 58: 3047-3052, 1992.

GOESTCH, A. L. \& OWENS, F. N. Effects of sampling site on passage rate estimate in heifers fed alfafa hay or a high concentrate diet. Journal of Dairy Science, Champaign, 68: 914-22, 1985

GORDON, F. J. A further study on the evaluation through lactating cattle of a bacterial inoculant as an additive for grass silage. Grass and Forage Science, Oxford, A. Younger, 44: 353-357, 1989.

HENDERSON, A. R. \& McDONALD, P. Effect of formic acid on the fermentation of grass of low dry matter content. Journal of the Science of Food and Agriculture, Cambridge, 22: 157-163, 1971.

HENDERSON, A.R. \& McDONALD, P. The effect of cellulase preparations on the chemical changes during the ensilage of grass in laboratory silos. Journal of the Science of Food and Agriculture, Cambridge, 28: 486-90, 1977.

HERON, S. J. E.; EDWARDS, R. A.; McDONALD, P. Changes in nitrogenous components of gamma-irradiated and inoculated ensiled ryegrass. Journal of the Science of Food and Agriculture, Blackwell Scientific Publications, 37(10): 979-985, Oct. 1986.

HUNT, C.W.; KEZAR W.; VINANDE R. Yield, Chemical Composition and Ruminal Fermentability of Corn Whole Plant, Ear and Stover as Affected by Maturity. Journal Production of. Agriculture, 2(4): 357-61, 1989. 
JOHNSON, R. R.; BALWANI, T. L.; JOHNSON, L. J.; McCLURE, K. E.; DEHORITY, B. A. Corn plant maturity. II. effect on in vitro cellulose digestibility and soluble carbohydrate content. Journal of Animal Science, Menasha, 25: 617-623, 1966.

JONES, B. A.; HATFIELD, R. D.; MUCK, R. E. Effect of fermentation and bacterial inoculation on lucerne cell walls. Journal of Science Food Agriculture, Cambridge, 60(2):147-153, 1992.

KEADY, T. W. J.; STEEN, R. W. J.; KILPATRICK, D. J.; MAYNE, C. S. Effects of inoculant treatment on silage fermentation, digestibility and intake by growing cattle. Grass and Forage Science, Oxford, A. Younger, 49(3): 284-294. set. 1994.

KENNEDY, S. J.; GRACEY, E. F.; UNSWORTH, E. F.; STEEN, R. W. J.; ANDERSON, R. Evaluation studies in the development of a commercial bacterial inoculant as an additive for grass silage. 2 . Responses in finishing cattle. Grass and Forage Science, Oxford, A. Younger, 44: 371-380, 1989.

KRISHNAMOORTHY, U.; MUSCATO, T.V.; SNIFFEN, C.J.; VAN SOEST, P.J. Nitrogen fractions in select feedstuffs. Journal of Animal Science, Champaign, 65: 217-225, 1982.

KUNG JR. L.; CARMEAN, B. R.; TUNG, R. S. Microbial inoculation or cellulase enzyme treatment of barley and vetch silage harvested at three maturities. Journal of Dairy Science, Champaign, 73: 1304$1311,1990$.

KUNG JR., L.; CHEN, J. H.; KRECK, E. M.; KNUTSEN, K. Effect of microbial inoculants on the nutritive value of corn silage for lactating 
dairy cows. Journal of Dairy Science, Champaign, 76(12):37633770, Dez. 1993.

LIN, C.; BOLSEM, K. K.; BRENT, B. E.; FUNG, D. Y. C. Epiphytic lactic acid bacteria succession during the pre-ensiling and ensiling periods of alfafa and maize. Journal of Applied Bacteriology, Reading, 73: 375-387, 1992.

LINDGREN, S.; PETERSSON, K.; KASPERSSON, A.; JONSSON, A.; LINGVALI, P. Microbial dynamics during aerobic deterioration of silages. Journal of the Science of Food and Agriculture, Cambridge, 36: 765-774, 1985.

LISSETE, L.; ESPERANCE, M.; OJEDA, F.; CÁCERES, O.; SANTANA, H. Fermentacion de ensilajes tropicales con la utilizacion de bacterias acido lacticas aisladas en Cuba. Pastos y Forrajes, Cuba, 15:63-69, 1992.

LUTHER, R.M. Effect of microbial inoculation of whole-plant corn silage on chemical characteristics, preservation and utilization by steers. Journal of Animal Science, Albany, 63: 1329-1336, 1986.

MAHANNA, B. Troubleshooting silage proplems. Pioneer Hi-bred International Inc. mai. 1995.

McDONALD, P.; HENDERSON, A. R.; HERON, S. J. E. The biochemistry of silage. Edinburg, J. Wiley and Sons Ltda, 1991. $226 \mathrm{p}$.

MEHREZ, A. Z.; ORSKOV, E. R. A study of the artificial fibre bag technique for determining the digestibility of feeds in the rumen. Journal Agriculture of Science, Cambridge, 88: 645-650, 1977. 
MERRY, R. J.; DHANOA, M. S.; THEODOROU, M. K. Use of freshly lactic acid bacteria as silages inoculants. Grass and Forage Science, Oxford, A. Younger, 50(2):112-123, 1995.

MERRY, R.J.; MACKENNA, C.; JONES, RAYMOND. Biological silage addtives. Ciência e Investigacion Agraria, Santiago, 20(2): 372401, ago. 1993.

MERRY, R. J.; TEODOROU, M. K.; BEEVER, D. E.; LEEMANS, D. K.; THOMAS, C. A novel approach to the use of silage inoculants. Animal Production, 50:363, 1990.

MORRISON, I. M. Changes in the cell wall of laboratory silages and the effect of various additives on these changes. Journal of Agriculture Science, Cambridge, 93:581-586, (1979)

MUCK, R. E. Factors Influencing Silage Quality and Their Implication for Management. Journal of Dairy Science, Champaign, 71:2992-3002, 1988.

MUCK, R. E. Initial bacterial numbers on lucerne prior to ensiling. Grass and Forage Science, Oxford, A. Younger, 44(1):19-26, 1990.

NESBAKKEN, T. \& BROCH-DUE, M. Effects of a commercial inoculant of lactic acid bacteria on the composition of silages made from grasses of low dry matter content. Journal of Science Food Agriculture, Cambridge, 54: 177-190, 1991.

NOCEK, J. E. In situ and other methods to estimate ruminal protein and energy digestibility: a review. Journal of Dairy Science, Champaign, 60: 1347-57, 1988. 
ORSKOV, E. R. \& McDONALD, I. The estimation of protein degradability in the rumen from incubation measurements weighted according to rate of passage. Journal of Agricultural Science, Cambridge, 92: 499-503, 1979.

OSTLING, C.; LINDGREN, S. Bacteria in manure and on manured and NPK-fertilized silage crops. Grass and Forage Science, Oxford, A. Younger, 55(4):579-588, 1991.

OSTLING, C.; LINDGREN, S. Influence of enterobacteria on the fermentation and aerobic stability of grass silages. Grass and Forage Science, Oxford, A. Younger, 50(1):41-47. 1995.

PAHLOW, G. Microbiology of inoculants, crop and silages - small scale silage experiments. Procedings of the eurobac conference. Grass and Forage Reports, Swedish University of Agricultural Sciences, 3: 4549, 1990 (resumo).

PATTERSON, L. K. \& LINDGREN, S. The influence of the carbohydrate fraction and additives on silage quality. Grass and Forage Science, Oxford, A. Younger, 45:223-233, 1990.

PEREIRA, J. R. A. Avaliação das sub-frações dos carboidratos e das proteínas da silagem de milho, farelo de algodão e milho, usando a metodologia do CNCPS e "in situ", com bovinos da raça nelore. Piracicaba, 1995. 94p. (dissertação de Mestrado-Escola Superior de Agricultura "Luiz de Queiroz"/USP).

PEREIRA, J. R. A. \& ROSSI, P. Manual prático de avaliação nutricional de alimentos. Piracicaba, FEALQ, 1995. 25p. 
PETIT, H. V.; RIOUX, R.; TREMBLAY, G. F. Evaluation of forages and concentrates by the "in situ" degradability technique. In: SIMPÓSIO INTERNACIONAL DE PRODUÇÃO DE RUMINANTES; REUNIÃO ANUAL DA SOCIEDADE BRASILEIRA DE ZOOTECNIA, 31, Maringá, 1994. Anais. Maringá, SBZ, 1994. p.119-33.

ROOKE, J. A.; MAYA, F. M.; ARNOLD, J. A. ARMSTRONG, D. G. The chemical composition and nutritive value of grass silages prepared with no additive or with the application of additives containing either Lactobacillus plantarum or formic acid. Grass and Forage Science, Oxford, A. Younger, 43(1): 87-95, 1988.

ROSZAK, D. B. \& COLWELL, R. R. Metabolic activity of bacterial cells enumerated by direct viable count. Applied and Envimental Microbiology, Baltimore, 53: 2889-2893, 1987.

SANDERSON, M. A. Aerobic stability and in vitro fiber digestibility of microbially inoculated corn and sorghum silages. Journal of Animal Science, Menasha, 71: 505-514. 1993.

SAS Institute Inc. SAS/STAT User's Guide, ed. CARY, NC, 1988.

SCHAEFER, D.M.; BROTZ, P.G.; ARP, S.C.; COOK, D.K. inocultation of corn silage and high-moisture corn with lactic acid bacteria and its effects on the subsequent fermentations and on feedlot performance of beef steers. Animal feed Science and Technology, Amsterdam, 25:23-38, agos. 1989 .

SEALE, D. R. Bacterial inculants as silage addtives. Journal of Applied Bacteriology Symposium Supplement. 1986. 
SETALA, J. Enzymes in grass silage production. Food and Biotechnology, 2: 211-225, 1989.

SHARP, R.; HOOPER, P. G.; ARMSTRONG, D. G. The digestion of grass silages produced using inoculants of lactic acid bacteria. Grass and Forage Science, Oxford, A. Younger, 49 (1): 42-53, 1994.

SUSMEL, P.; STEFANON, B.; MILlS,C. R.; SPANGHERO, M. Rumen degradability of organic matter, nitrogen and fiber fractions in forages. Animal Production, London, 51(3): 515-26, 1990.

THIAGO, L. R. L. S. Utilização da técnica da degradabilidade in situ para avaliação de forragens e alimentos concentrados. In: SIMPÓSIO INTERNACIONAL DE PRODUÇÃO DE RUMINANTES; REUNIÃO ANUAL DA SOCIEDADE BRASILEIRA DE ZOOTECNIA, 31, Maringá, 1994. Anais. Maringá, SBZ, 1994. p.89-93.

TJANDRAATMAJA, M.; NORTON, B. W.; MAC RAE, I. C. A numerical taxonomic study of lactic acid bacteria from tropical silages. Journal of Applied Bacteriology, Reading, 68: 543-553, 1990.'

ÚDEN, P.; COLUCCI, P. E.; VAN SOEST, P.J. Investigation of chromium, cerium and cobalt as markers in digesta. Rate of passage studies. Journal Science Food Agriculture, 31:625-31, 1980.

VALADARES FILHO, S. C. Utilização da técnica "in situ" para avaliação dos alimentos. In: SIMPÓSIO INTERNACIONAL DE PRODUÇÃO DE RUMINANTES; REUNIÃO ANUAL DA SOCIEDADE BRASIlEIRA DE ZOOTECNIA, 31 Maringá, 1994. Anais, Maringá, SBZ, 1994. p.95-118. 
VALADARES FILHO, S. C.; COELHO SILVA, J. F.; LEÃO, M. I.; EUCLYDES, R. F.; VALADARES, R. F. D.; CASTRO, A. C. G. Degradabilidade "in situ" da proteína bruta e matéria seca de alguns alimentos em vacas gestantes e lactantes. Revista da Sociedade Brasileira de Zootecnia, Viçosa, 20(1): 111-22, 1991.

VAN SOEST, P. J. Nutritional ecology of the ruminant, Ithaca, University Press, 1982. 373p.

VAN SOEST, P. J. \& ROBERTSON, J. B. Analysis of forages and fibrous foods. Cornell University. 1985. 202p.

VAN VUUREN, A.M.; BERGSMA, K.; FROL-KRAMER, F. \& VAN BEERS, J.A.C. Effects of addition of cell wall degrading enzymes on the chemical composition and the in sacco degradation of grass silage. Grass and Forage Science, Oxford, A. Younger, 44: 223-230, 1989.

VILELA, G. L.; Degradabildiade in situ da matéria seca e da proteína bruta de vários alimentos em vacas alimentadas com diferentes ração. Viçosa, 1994. 68p. (MS-Universidade Federal de Viçosa).

WEDDELL, J. R. \& YACKIMINIE, D. S. The efects of ecosyl, scotisil and add-f treated grass silages on the intake and performance of friesian steers. Animal Prodution, Londres, 44(3): 494, jun. 1987. resumo.

WEISS, W. P.; CONRAD, H. R.; PIERRE, N. R. St. A theoretically-based model for predicting total digestible nutrient values of forages and concentrates. Animal Feed Science and Technology, Amsterdam, 39: 95-110, 1992. 
WITTENBERG, K. M.; INGALLS, J. R.; DEVLIN, T. J. The effect of lactobacteria inoculation on corn silage preservation and feeding value for growing beef animals and lambs. Canadian Journal Animal Science, Ottawa, 63: 917-924, Dez. 1993.

WOOLFORD, M. K. The silage fermentation. New York, Marcel Dekker Inc., 1984. $280 \mathrm{p}$.

WOOLFORD, M. K. \& SAWCZYC, M. K. An investigation into the effect of cultures of lactic acid bacteria on fermentation in silage. 1. Strain selection. Grass and Forage Science, A. Younger, 39:139-148, $1984 \mathrm{a}$.

WOOLFORD, M.K. \& SAWCZYC, M.K. An investigation into the effect of cultures of lactic acid bacteria on fermentation in silage. 2. Use of selected strains in laboratory-scale silages. Grass and Forage Science, Oxford, A. Younger, 39(4):149-158, jun. 1984b. 